\title{
切欠底から発生する微視・微小き裂の疲労き裂 寿命評価法について
}

「発生と伝播の統一理論による寿命予測のアルゴリズム」

— RPG 規準による疲労き裂伝播挙動の研究（第 4 報）——

\section{正員 豊 貞 雅 宏* 正員 丹 羽 敏 男*}

Assessment of Fatigue Life for a Crack Emanated from a Notch

-Algorithm of Fatigue Life Assessment by $\Delta K_{\mathrm{RP}}$ Approach without Distinguishing between the Crack Initiation and the Propagation-

by Masahiro Toyosada, Member Toshio Niwa, Member

\begin{abstract}
Summary
In the previous paper, we showed that logarithmic curve of $\Delta K_{\mathrm{RP}} \sim d a / d N$ was linear even in the ranges of stages I and II of a long crack. In other words, threshold phenomenon appears only circumstantially due to applying $\Delta K$ or $\Delta K_{\text {eff }}$ which involve the term not related to the crack extension force such as elastic deformation in addition to the term related to the crack driving force.

In this paper, we carried out fatigue crack initiation/propagation test for CT specimens with a notch of root radius $1 \mathrm{~mm}$. Fatigue cracks initiated in the mid-thickness at a notch root as surface cracks. Having considered the change of an aspect ratio of surface cracks before and after coalescence from previous studies for a surface crack propagation and a change of measured RPG load (Re-tensile Plastic zone's Generated load), it was confirmed that the logarithmic curve of $\Delta K_{\mathrm{RP}} \sim d a / d N$ for a physically small crack of which the length was greater than one microstructural grain size and smaller than a uniform through-thickness crack was in good agreement with that for a long crack.

Moreover, for a microstructural short crack which is less than one grain size, it is postulated that dislocations do not exceed beyond barriers such as a grain boundary and a pearlite zone in a ferritepearlite microstructure when loading range appearing tensile plastic zone keeps constant. Then, the equivalent $\Delta K$ value is obtained from a plastic zone size. Therefore, from the measured RPG load, equivalent $\Delta K_{\mathrm{RP}}$ is defined for a microstructural short crack, relating that $\Delta K_{\mathrm{RP}}$ represents compressive plastic zone at minimum load for a long crack. By using equivalent $\Delta K_{\mathrm{RP}}$ for a microstructural short crack and $\Delta K_{\mathrm{RP}}$ for a physically small crack and a long crack, crack propagation curves are calculated for a crack emanated from a notch root without distinguishing between crack initiation and propagation. The calculated crack propagation curves are in very good agreement with experimental ones.

These results indicate that the fatigue life can be prolonged if the grain size is made small. However, we might not be able to expect any drastic improvement if the maximum grain size is greater than about $10 \mu \mathrm{m}$. Moreover qualitative studies were also made for the phenomenon about stopping crack and coaxing effect by using the algorithm.
\end{abstract}

\section{1. まえがき}

疲労寿命は，き裂発生寿命とき裂伝播寿命の和として与

* 九州大学工学部

原稿受理 平成 5 年 7 月 8 日

秋季講演会において講演 平成 5 年 11 月 9,10 日
えられる。前者は $S-N$ 曲線で, 後者は破壊力学的手法で推 定されてきた。しかし, $S-N$ 曲線で求められる発生寿命が, 実構造物においていくらの大きさのき裂に対応するか未だ 明確になっていない。このき裂，すなわち破壊力学を適用 する際の初期き裂の与え方で全寿命の推定はいかようにで もなり, 損傷解析では適時都合の良い初期き裂が採用され るのが現状である。 
したがって, 疲労寿命評価を信頼あるものとならしめる ためには，上記のギャップをなくすようにするか，発生と 伝播を同一体系化で統一して評価できるようにすることが 必要となる。

破壊力学で取扱う対象き裂を小さいところへまで拡張す る努力はこれまで多くなされてはいるが，この時問題とな るのは微小き裂あるいは結晶粒オーダ以下の微視き裂で は，長いき裂で得られる $\Delta K_{\mathrm{th}}$ よりも小さな $\Delta K$ 以下でき 裂が伝播することであり, 見掛け上 $\Delta K_{\mathrm{th}}$ は微視き裂, 微小 き裂では小さくなると考えた解析が行われている1”。か し，なぜき裂が短くなると $\Delta K_{\mathrm{th}}$ が低くなるのかの物理的 意味は考察されていない。

ところで, 著者ら ${ }^{2)}$ は, 負荷過程中に引張塑性域が生じ出 す時点の荷重 $P_{\mathrm{RPG}}$ から最大荷重 $P_{\max }$ の荷重範囲に対応す る応力拡大係数範囲 $\Delta K_{\mathrm{RP}}$ と疲労き裂伝播速度 $d a / d N$ と の間には, 極低き裂伝播速度領域も含めて両対数グラフ上 で直線関係が存在することを示した。このことは， $\Delta K_{\mathrm{th}}$ は き裂の伝播に真に寄与する成分だけを表したき裂伝播パラ メータを採用していないために存在するもので, 材料定数 ではないものと解釈される。

そこで, 本研究では切欠底を円弧状に仕上げた CT 試験 片を用いて疲労試験を実施し, 切欠底から発生・伝播する 微小き裂に対する $\Delta K_{\mathrm{RP}} \sim d a / d N$ 関係が長いき裂のそれに 一致するか否かをまず検討した。この微小き裂は非貫通き 裂となるので, この効果を考慮することにより両者が一致 することを示した。

ところで, 最小荷重時に生じるき裂先端前方の圧縮塑性 領域 $\tilde{\omega}$ のが繰り返し荷重下で塑性ヒステリシスループ を生じる領域となるため, この領域で疲労被害が蓄積され ると考えられる。そこで, 長いき裂では $\Delta K_{\mathrm{RP}}$ がこの圧縮塑 性領域の寸法を間接的に表していることを示した。

そして，これまでの微視き裂の研究成果 ${ }^{3)}$ を参考とし塑 性域が生じている荷重範囲が一定の場合, すなわち有効荷 重範囲 $\Delta P_{\mathrm{RP}}$ が一定の場合には切欠底から発生したき裂が 最初の結晶粒界に到達するまでは圧縮塑性域の成長は結晶 粒界などのバリヤで拘束されているとの仮定を導入して, 長いき裂で得られた $\Delta K_{\mathrm{RP}} \sim d a / d N$ 関係から初期き裂の存 在を仮定しないでき裂成長曲線を近似的に推定するアルゴ リズムを提案した。

その結果, 推定曲線と実験結果は非常に良い一致がみら れた。そして, 結晶粒径が細かくなるほど疲労寿命が長寿 命になることを示した。さらに，このアルゴリズムにより 切欠底に生じる停留き裂の現象およびコーキシング効果が 説明できることを定性的に明らかにした。

\section{2. 供試材および試験方法}

供試した鋼板は SM-41 B 鋼であり, 前報2)で用いた鋼板 と同じである。この供試材より Fig. 1 に示す CT 試験片を
採取した。図に示すように，切欠先端部は半径 $1 \mathrm{~mm}$ の円 弧状にしている。残留応力を除去する目的で試験片を作成 後, $620^{\circ} \mathrm{C}, 2 \mathrm{hr}$ 保持の条件で熱処理を施している。Fig. 2 には供試材のミクロ組織を示す。疲労き裂の伝播方向は紙 面の横方向であり, 平均結晶粒径は約 $30 \mu \mathrm{m}$, 最大結晶粒 径は約 $60 \mu \mathrm{m}$ である。この鋼板の長いき裂に対する疲労き 裂伝播速度は，ステージI およびステージIIの広領域にお いて

$$
\frac{d a}{d N}=4.505 \times 10^{-11}\left(\Delta K_{\mathrm{RP}}\right)^{2.692} \quad \text { (SI 単位表示) }
$$

で表される2)。

疲労き裂伝播試験は，先に開発した高精度コンプライア ンス測定システムを適用して, 応力比 $0.05,0.3$ および 0.5 の一定荷重振幅下を意図して行った。ただし，適用した試 験機の油圧源容量が小さいにもかかわらず， $15 \mathrm{~Hz}$ という 高速で繰り返し荷重を与えたので，き裂長さが大きくなる につれ最大荷重は小さく最小荷重は大きくなる事情は前

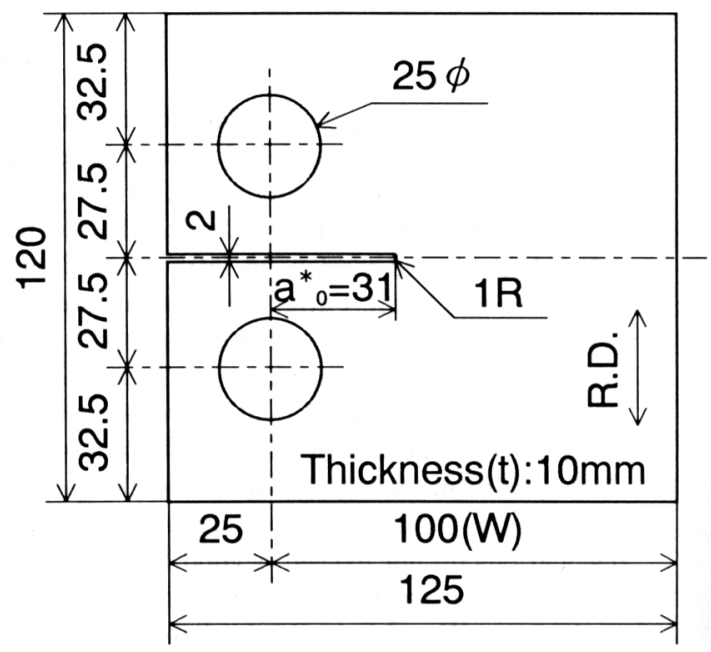

Fig. 1 CT specimen used

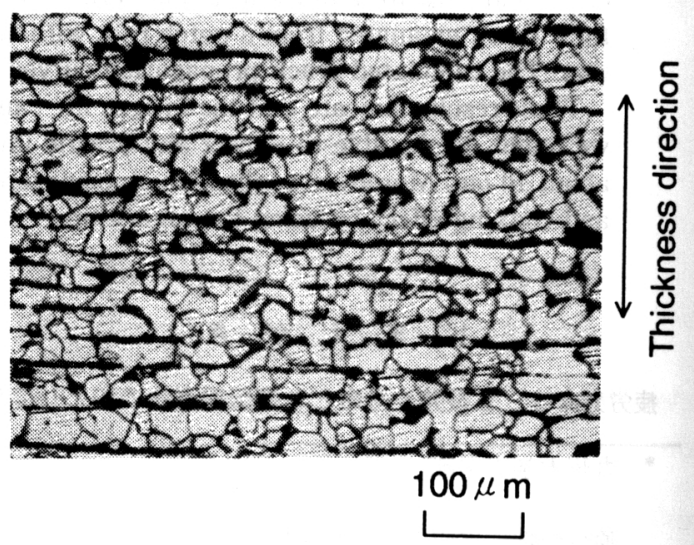

Fig. 2 Microstructure of SM-41B steel used 
報゙と同じである。

\section{3. 切欠底に発生・伝播する表面き裂のアスペクト比 の変化}

Fig. 1 に示す試験片では, 疲労き裂は切欠底の板厚中央 部から多数点発生し，これらが成長する過程で合体を繰り 返し，ついにはFig. 3 に示すような単一の表面き裂となり さらに成長すると貫通き裂になるものと考えられる。

ところで，川原ら ${ }^{4}$ は平板に存在する単一の表面き裂が 繰り返し荷重により伝播する場合, 曲げ荷重比 $\alpha(=$ 引張応 力振幅/(引張応力振幅＋曲げ応力振幅))が一定ならばき裂 深さ $a$ と表面き裂半長 $c$ との比, すなわちアスペクト比 $(a / c)$ が板厚貫通時にほほ一定になることに着目し，伝播 中のアスペクト比変化に関する実験式を提案している。 Fig. 4 は, 彼らの提案式の模式図である。初期欠楩が非常に 浅く，その表面におけるき裂半長 $c_{0}$ が深さ $a_{0}$ とほほ等し い場合のき裂伝播形状は図中の $f(a / t)$ に沿って伝播する。 ただし, $t$ は板厚である。この場合の伝播を彼らは均衡成長 と呼んでいる。 $f(a / t)$ は $\alpha$ の関数であり次式で与えられて いる。

$$
f(a / t)=a / c=A-B \cdot(a / t)
$$

ここで

$A=0.98+0.07 \alpha, B=0.06+0.94 \alpha$

一方, 初期欠陥が非常に偏平な場合には点 $\left(a_{0} / t, a_{0} / c_{0}\right)$ と原点を通る直線 $g(a / t)$ と (2) 式の $f(a / t)$ の 2 つの直線 を漸近線とする

$$
\frac{1}{(a / c)^{n}}=\frac{1}{\{f(a / t)\}^{n}}+\frac{1}{\{g(a / t)\}^{n}}
$$

ただし

$n=1+m / 2 \quad(m:$ Paris 則の指数 $)$

に沿って変化する。この場合を彼らは非均衡成長と呼んで いる。

( 3 ) 式は $a_{0}$ が小さい場合には初期欠陥の点 $\left(a_{0} / t, a_{0} / c_{0}\right)$ をほほ通るが, ある程度深くなると通らないので以下のよ うに修正する必要がある5)。

$$
c=a\left\{\left(\frac{1}{A-B a / t}\right)^{n}+\left(\frac{\beta t}{a}\right)^{n}\right\}^{1 / n}
$$

ただし

$$
\beta=\frac{a_{0}}{t}\left\{\left(\frac{c_{0}}{a_{0}}\right)^{n}-\left(\frac{1}{A-B a_{0} / t}\right)^{n}\right\}^{1 / n}
$$

上記のように, 平板に存在する単一表面き裂では均衡成 長の場合アスペクト比はき裂深さに対して直線的に変化す る。切欠底に存在する表面き裂の $K$ 值は切欠による応力集 中のため, 平板中に同じ大きさの表面き裂がある場合の $K$ 值より増加するが，その増加の程度は切欠底に近いき裂前 縁ほど大きくなる6)。したがって，切欠底における表面き裂 の均衡成長は平板中における表面き裂より偏平な形となる はずである。

Fig. 1 の CT 試験片の場合, き裂がある程度成長すると
板厚貫通き裂となるが，貫通直後は板厚中心部のき裂長さ が板表面よりも大きいので一様な貫通き裂として取扱うこ とができない場合も生じる。すなわち，板厚が大きい場合 には, 板厚貫通以前でも板厚中央部ではほほ一様なき裂深 さとなり貫通き裂として近似的に取扱うことができる場合 もあると考えられるが，板厚が小さい場合には，たとえ板 厚貫通裂になっていても一様な貫通き裂として近似できな い場合も生じるものと考えられる。したがって，どの時点 で一様な貫通き裂として取扱えるようになるかが問題とな る。

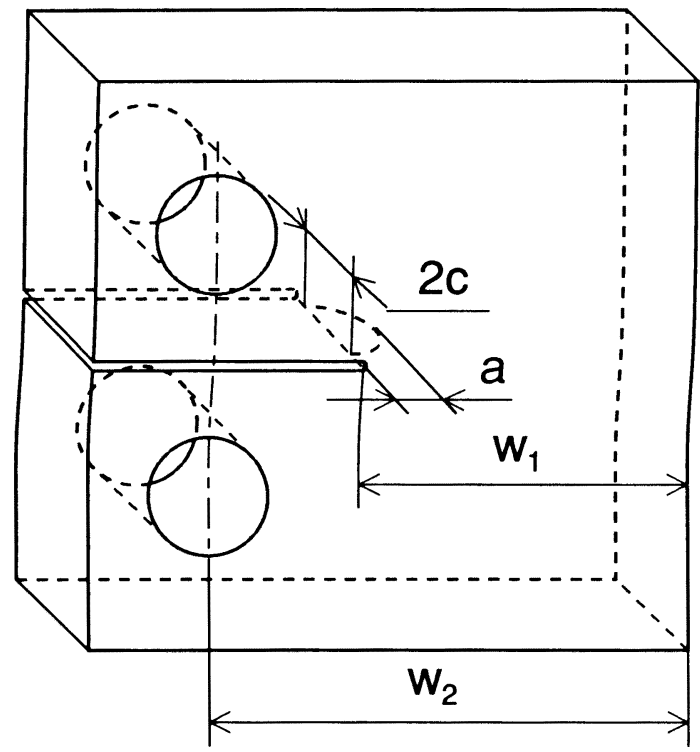

Fig. 3 Schematic diagram of surface crack initiated at a notch root

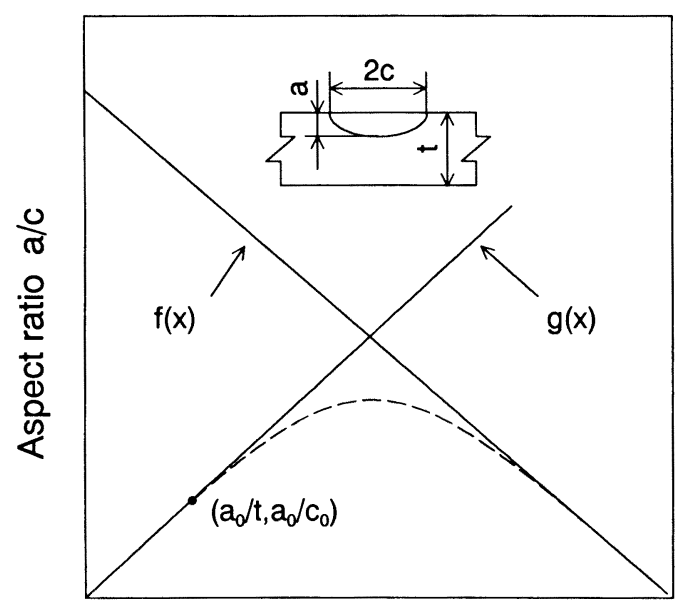

Normalized crack size a/t

Fig. 4 The change of aspect ratio for surface cracks 
これまでの計測結果 ${ }^{2), 7)}$ によると, RPG 荷重は切欠の応 力集中係数が大きい場合はき裂発生後き裂の成長とともに 大きくなり，あるき裂長さのところで最大値を示し，その 後き裂の成長とともに徐々に小さくなる。一方, 応力集中 係数が比較的小さい場合はき裂発生直後はき裂の成長につ れて小さくなり，極小值を示した後き裂の成長とともに大 きくなり，あるき裂長さのところで極大值を示した後き裂 の成長とともに徐々に小さくなる。

RPG 荷重が最大値あるいは極大值を示す時点は, き裂閉 口域が十分に発達した時点と対応する。その後は定常状態 となり, $\Delta K_{\mathrm{RP}}$ は徐々にき裂成長とともに変化する。切欠底 から伝播したき裂が $\Delta K \sim d a / d N$ のステージII 線上に乗 るのはこの時点以後のき裂長さの領域と考えられる。なぜ なら, 定常状態に入る直前では, 有効荷重（=最大荷重一 $\mathrm{RPG}$ 荷重： $\Delta P_{\mathrm{RP}}$ ) はき裂の成長とともに小さくなり, $\Delta K_{\mathrm{RP}}$ の変化は定常状態よりもき裂の成長に対して小さくなり, ステージII線上からはずれるものと考えられる。

したがって，一様な貫通き裂とみなして評価できる領域 は RPG 荷重が最大值あるいは極大值を示してから以後の き裂長さと想定できる。

そこで, Fig. 1 に示した試験片と切欠底半径を $2 \mathrm{~mm}$ (他 は Fig. 1 と同じ寸法，形状)の 2 体を用いて応力比 0.05 の 条件下で疲労き裂伝播試験を実施し，き裂伝播形状を測定 する目的でビーチマークを導入すると同時に, RPG 荷重を 計測する目的で微小なコンプライアンス変化も計測した。 Fig. 5 a)，b）にはそれらの破面と RPG 荷重の測定結果も 合わせて示してある。
そこで，き裂深さ $a$ を RPG 荷重が極大值を示すき裂深 さ $a_{1}$ で無次元化し， $a$ が $a_{1}$ のときにアスペクト比 $(a / c)$ が 0 となる均衡成長の予測直線を Fig. 5 の点線のように 求めた。ただし，ここでは $a$ が平均結晶粒径 $30 \mu \mathrm{m}$ のとき に $a / c$ が 1 となると川原らの結果から仮定した。図中には ビーチマークにより得られたアスペクト比も示した。微小 き裂領域であるため得られたき裂形状は試験片 1 体あたり 1 点であるが少なくとも合体後のアスペクト比の変化は上 記のように仮定してもよさそうである。

飯田ら ${ }^{8)}$ は, 大きさの異なる $2 つ の$ 半棈円切欠を有する 平板に繰り返し荷重を負荷した場合のき裂伝播形状ならび にき裂成長曲線を推定する手法を提案している。Fig. 6 に はビーチマーク法により得られた結果をもとに同一平面内 にある 2 つき裂の疲労によるき裂成長過程を模式的に示 す。き裂が表面で合体する(3)までの過程では，近接する他 のき裂のため単独に存在する同じ大きさのき裂の $K$ 值よ り $K$ 值が大きくなり,いわゆる干涉効果によりき裂の成長 は速くなる。一方，合体後単一の半楕円き裂となる(5)まで の過程では, 合体後の全き裂表面長さの半分を長軸, 最も 深いき裂の深さを短軸とする半楕円き裂の $K$ 值より $K$ 值 は小さくなる。なお，合体直後のき裂深さの浅い個所は $K$ 值が他の部分より卓越して大きくなるために，この個所の き裂成長は速くなりき裂前縁線が滑らかな半棈円形状に変 化する。

そこで, 彼らは(3)までの過程では干涉効果を無視し, そ れぞれのき裂が単独で成長するとして長寿命側の評価を与 え, (3)から(5)区間の寿命を無視し，(5)から後の過程では
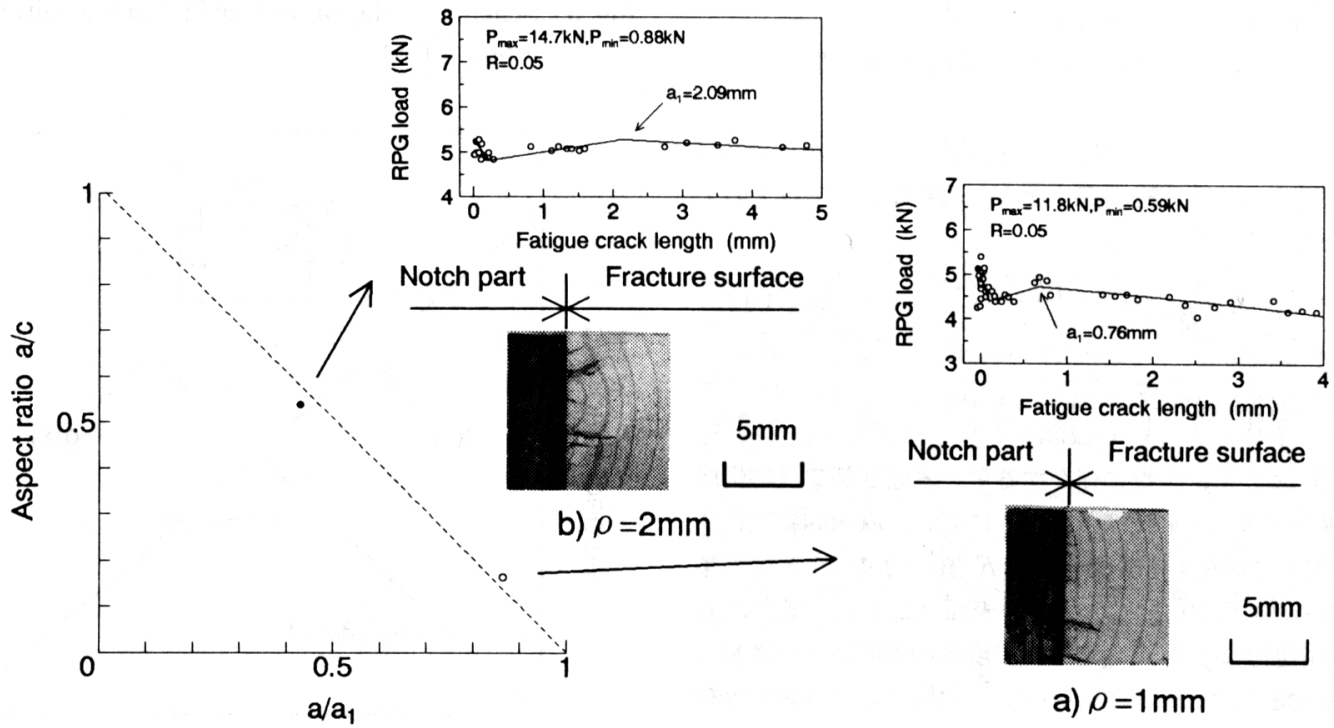

a) $\rho=1 \mathrm{~mm}$

Fig. 5 The change of aspect ratio of surface cracks emanated from various notch roots 
(1) initial crack

(2) before coalescence

(3) at coalescence

(5) complete coalescence

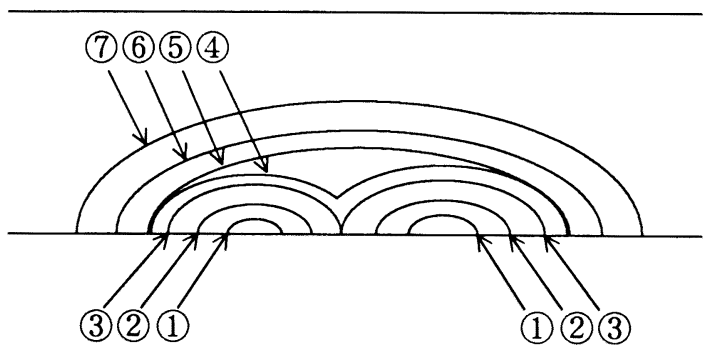

Fig. 6 Surface crack propagation before and after coalescence

合体後の全き裂表面長さの半分を長軸，最も深いき裂の深 さを短軸とする半棈円き裂と仮想してき裂の成長を評価し た。(3)までの長寿命側の評価を(3)から(5)の区間の寿命を無 視することでほぼ妥当な寿命評価が行えるとしている。

これらの結果より，初期き裂(1)の深い方およびき裂合体 後き裂前縁線が滑らかな半棈円形状に成長した(5)の時点を $a / c \sim a / t$ 図上にプロットし，この両者を結ぶ直線に沿って き裂形状が変化するとあたかも仮想し，(5に達した時点か らは Fig. 6 のように一つのき裂として取扱うとき裂合体 前および合体後のき裂成長をほぼ妥当に評価できる可能性 がある。

そこで, 飯田ら ${ }^{8)}$ が解析した日本溶接協会 6 AFC 小委員 会9)で行われた曲げ荷重下の試験結果を再解析した。ここ で, 曲げ荷重下のデー夕を取り上げたのは CT 試験片での 切欠底では応力勾配が急であるためである。Fig. 7 亿試験 片 $6 \mathrm{~B} 4 \mathrm{Q}$ のアスペクト比変化を示す。そこで, まず合体後 かなり成長した最終段階の結果より川原らの結果を使用し て均衡成長の直線を定め, 実験で行われた曲げ荷重比を求 めた。その結果, 曲げ荷重比を 0.98 とした均衡成長変化を 点線のようにすると (4)式より図に曲線で示すような非均 衡曲線が得られ, 妥当な(5)以後のアスペクト比の変化が評 価できる。ここで，曲げ荷重を与えているにもかかわらず 曲げ荷重比を 1 としなかった理由は曲げ荷重を 4 点曲げに より与えており, 摩擦により引張応力も少し加わっている と判断されるためである。そこで, (5)以前のき裂形状変化 を深い方の初期き裂と(5)のき裂より実直線のように仮想的 に考え，単一き裂問題として最深部の $K$ 值を Newman ら ${ }^{10)}$ の式により求め, 用いられた材料の $C, m$ 值を使用し て Paris 則によりき裂成長曲線を評価した。

その結果をFig. 8 に実線で示す。図中には実験結果も示 してある。さらに, 点線は飯田らの方法により評価された ものである。ただし，飯田らは単一表面き裂材の疲労き裂 伝播試験結果をもとに, A.S. Koboyashi が求めた $K$ 值 ${ }^{11}$

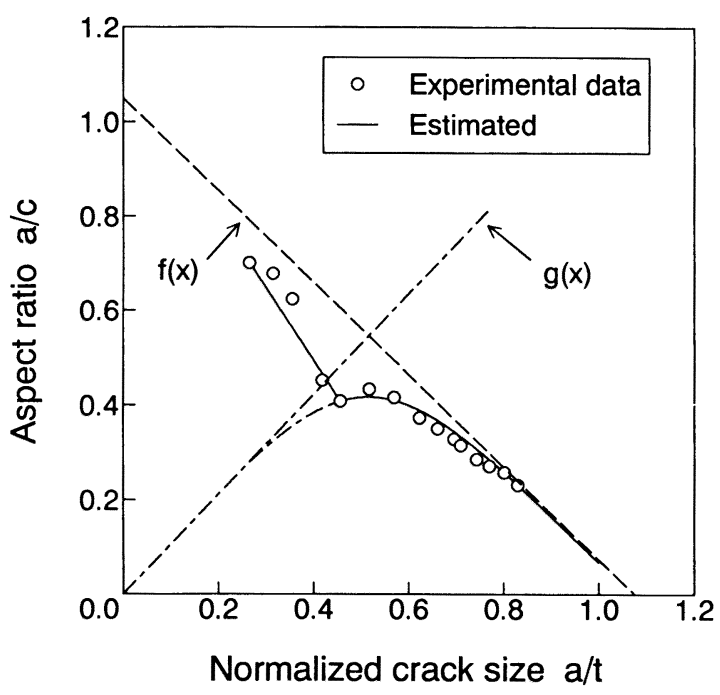

Fig. 7 The change of aspect ratio for $6 \mathrm{~B} 4 \mathrm{Q}$ specimen

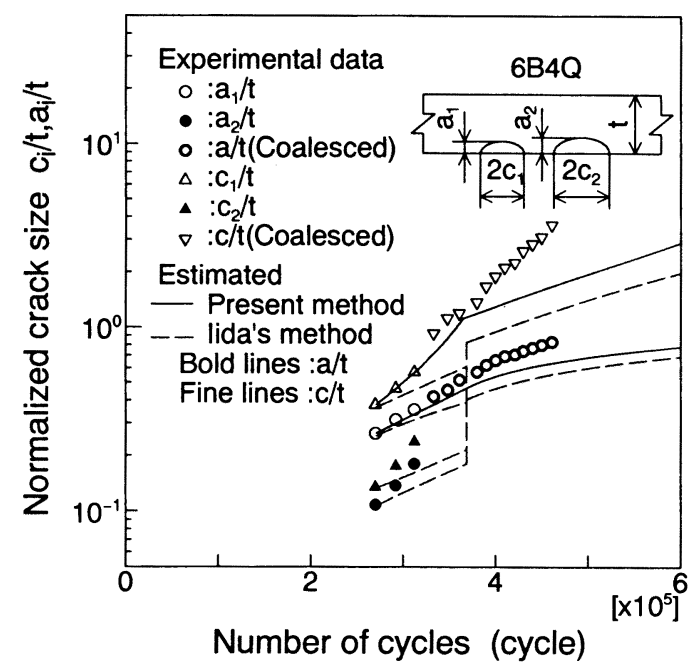

Fig. 8 Crack growth curve for $6 \mathrm{~B} 4 \mathrm{Q}$ specimen

を半実験的に修正した $K$ 值を用いて解析しているので, 上 記のようにき裂のアスペクト比を仮想的に与えた場合との 差を論じ得ないので，ここでは飯田らの計算手法にしたが い $K$ 值だけを Newman らによる $K$ 值を与えて解析しな おした結果を図中に示した。

上記の結果より, Fig. 7 中の実線のように仮想的な形状 変化を与えると合体前のき裂成長をほほ妥当に評価してい ると判断される。合体後に評価した寿命が実験值とかなり 異なっているのは, き裂開閉口挙動を無視しているためと 思われる。

ところで, 疲労き裂はせん断応力で発生するため, CT 試 験片では切欠底で荷重軸と $45^{\circ}$ 傾いた方向と結晶粒の过り 
方向（体心立方体では〈111〉方向）とがほぼ一致する結晶 粒内から起こると予想されるので, 板厚中央付近の三軸拘 束が高く荷重軸方向応力がほほ一様となる切欠底の複数個 所から生じ，その内の最も大きなき裂が核となり伝播する 過程で合体を繰り返すものと考えられる。切欠による応力 集中のため平板中のき裂より偏平なき裂形状で伝播し, 複 数個所からき裂が発生するため, 合体が終了後き裂前縁線 が滑らかな形状になった時点でもき裂深さは浅い。

Blom ら ${ }^{12)}$ は $2024 \mathrm{Al}$ 合金材より採取した浅い片側切欠 試験片を用いて $R=-1$ の条件で疲労試験を実施し, 切欠 底に発生した疲労き裂の大きさを観察している。表面き裂 半長 $c$ が $20 \mu \mathrm{m}$ のとき $a / c=0.9 て ゙, c=300 \mu \mathrm{m}$ のとき $a / c=0.6$ となりこの領域ではき裂の成長とともにアスぺ クト比が滅少していくことを報告している。一方, 寺崎ら ${ }^{13)}$ は軟鋼材より突き合わせ溶接形状を模擬した疑似余盛試験 片を切り出し, 疲労試験を行った。彼らは, 止端半径を 0.25 $\mathrm{mm}$ とし, 応力集中係数が $3 \sim 5$ の試験片に $R=-1$ の条件 下で曲げ荷重を与え, 停留き裂の大きさを観察した。その 結果, 深さ $60 \mu \mathrm{m}$, 表面き裂半長 $150 \mu \mathrm{m}$ の停留き裂が存在 していたと述べている。

切久底に発生するき裂が合体して 1 つのなめらかな半楕 円状き裂になる時点のアスペクト比は, 切欠底の応力勾配 と応力比に依存すると考えられる。西谷らが提唱している 切欠力学 ${ }^{14)}$ によれば, 切欠底部の応力勾配は切欠の曲率半 径のみに依存する。応力勾配が大きくなるほどき裂合体時 の a/c は小さくなると考えられるので Fig. 1 の試験片を $R=-1$ で試験したとすれば上記 Blom らの結果と寺崎ら による結果の中間のアスペクト比になると考えられる。

一方, 応力比が大きくなると最梁部も表面部も最小荷重 時に開口しやすくなるので, 当然き裂合体時の $a / c$ は応力 比の影響を受けるものと考元られる。後述の Fig. 12 中に 示すように，貫通き裂として取扱うことのできるき裂長さ $a_{1}$ は応力比が大きくなるほど大きくなっている。したがっ て，合体後ほほ均衡成長するようになると応力比が大きく なるほどアスペクト比は大きくなっている。この傾向はき 裂合体前にも生じるものと考えられるので, 応力比 $0.05 \sim 0.5$ の実験では上記 $R=-1$ の結果よりょり円形に 近い形で合体時のき裂が形成されるものと考えられる。

そこで, き裂の核となる微視き裂の深さを 1 結晶粒と仮 定し，そのアスペクト比を川原らおよび Blom らの結果よ り 1 と仮定し, Fig. 9 に示すように以後のアスペクト比の 変化を次に示すような 3 つの case に設定して検討するこ とにした。すなわち，a/cが初めから均衡成長する場合 (case A), Blom らの結果と同じアスペクト比変化を仮定 した場合 (case B)，および疑似溶接余盛試験片で得られた 情報をもとにした場合（case C) の 3 case を設定して以下 の検討を行うことにした。

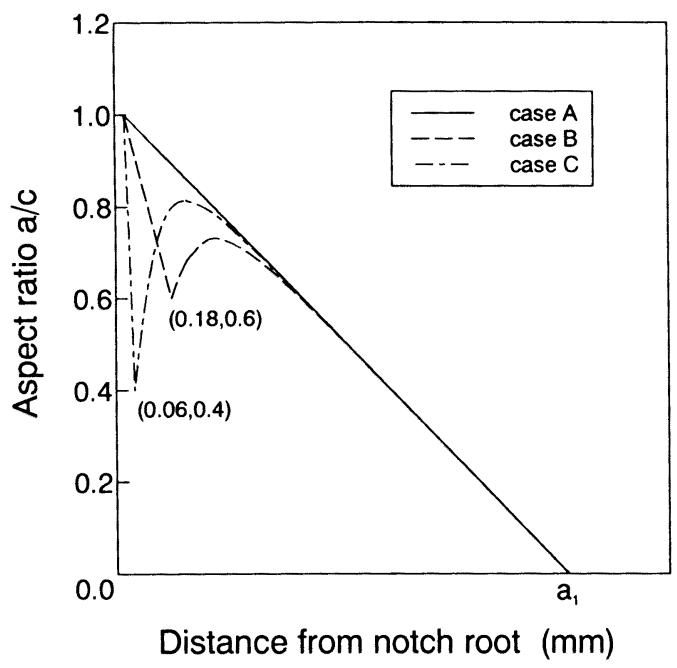

Fig. 9 The assumed change of aspect ratio of surface crack emanated from a notch

\section{4. 切欠底部から発生するき裂の $K$ 值}

前節に示したように疲労き裂は初めから板厚貫通き裂と して入るのではなく, 切欠底に半棈円状に入る。このよう な複雑なき裂の $K$ 值は求められていない。

そこで，まずFig.1に示すCंT試験片の切久底に微小な 板厚貫通き裂が存在する場合の $K$ 值 $\left(K_{1}\right)$ を境界要素法 ${ }^{15)}$ を用いて計算した。き裂先端部に応力ないしは変位の特異 性を有する特異要素を配置した。本境界要素法は, 境界積 分方程式の数值積分を適応的自動積分法を適用することに より精度向上が計られている。そして, 経路積分を行い $J$ 積分を求めそれより $K$ 值に変換した。Fig. 10 は, 得られた 解析結果をき裂長さの関係で示したものである。図中には, Srawley ${ }^{16)}$ によるCT 試験片の $K$ 值も同時に併記した。切

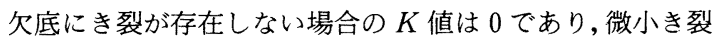
が入るとき裂成長にしたがい急激に上昇し，その後切欠を 含めた長さをき裂長と見なした場合の $K$ 值（Srawleyの 解）に漸近していき，ついには一致することがわかる。

そこで, 切久底に存在する半棈円表面き裂の最深部の $K$ 值をすみ肉溶接止端部に存在するき裂に対して Maddox

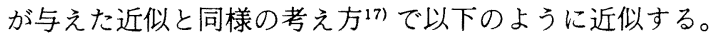

$K=K_{1} \cdot K_{2} / K_{3}$

ここで

$K_{1}$ ：切欠底にき裂長さ $a$ の貫通き裂が存在する場合 の $K$ 值 (Fig. 10 に示した $K$ 値)

$K_{2}$ : 表面き裂長 $2 c$, き裂深さ $a$ の半棈円表面き裂を 有する平板 (板厚 $w_{1}$ ) に一様引張応力が作用する 場合の $K$ 值

$K_{3}$ : 長さ $a$ の貫通き裂を有する端部き裂付き平板（板 幅 $w_{1}$ ）に一様引張応力が作用する場合の $K$ 值 


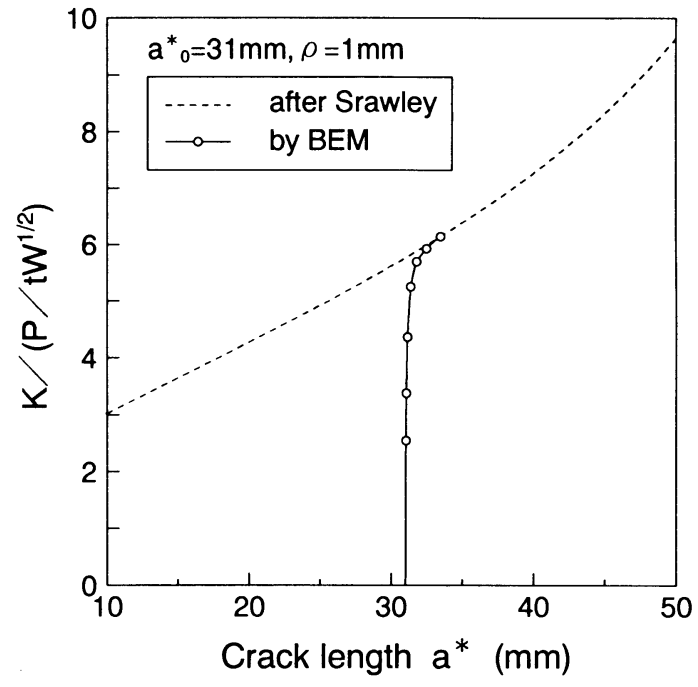

Fig. $10 \quad K$ value for CT specimen with a notch $\left(a_{0}^{*}=31\right.$ $\mathrm{mm}, \rho=1 \mathrm{~mm}$ )

ここで, $K_{2}$ は Newman ら ${ }^{11)} に よ る$ 結果より以下のように 与えられる。

$$
\begin{aligned}
& K_{2}=\sigma_{M} \sqrt{\pi a / Q} F \\
& \text { ただし } \\
& Q=1+1.464(a / c)^{1.65} \\
& F=M_{1}+M_{2}\left(a / w_{1}\right)^{2}+M_{3}\left(a / w_{1}\right)^{4} \\
& M_{1}=1.13-0.09(a / c) \\
& M_{2}=-0.54+0.89 /(0.2+a / c) \\
& M_{3}=0.5-1 /(0.65+a / c)+14(1-a / c)^{24}
\end{aligned}
$$$$
\text { また， } K_{3} \text { は以下ように与えられる }{ }^{18)} \text { 。 }
$$

$$
K_{3}=\sigma_{M} \sqrt{\pi a} F\left(a / w_{1}\right)
$$

ただし

$$
\begin{aligned}
& F\left(a / w_{1}\right)=\sqrt{\frac{2 w_{1}}{\pi a} \tan \frac{\pi a}{2 w_{1}}} \\
& . \frac{0.752+2.02\left(a / w_{1}\right)+0.37\left\{1-\sin \left(\pi a / 2 w_{1}\right)\right\}^{3}}{\cos \left(\pi a / 2 w_{1}\right)}
\end{aligned}
$$

なお, Fig. 8の6 AFC 小委員会デー夕の解析では試験片幅 の影響も Newmanらの $K$ 值に取り込んで解析したが,

（6 式では（この場合は板厚の影響となる）この影響は無 視している。その理由は， $K_{3} に$ 板厚の影響が含まれていな いことによる。また, 表面き裂の表面き裂長 $2 c$ が板厚より 大きくなると $(6)$ 式は成立しない。

$2 c$ が板厚よりも大きくなった場合は板厚中央部のき裂 が板表面部のき裂より長いパラボラ状のき裂となる。この

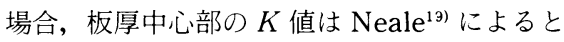

$$
K=\frac{t}{L} K_{1}
$$

\section{ただし（Fig. 11 参照）}

$K_{1}$ : パラボラ状のき裂の面積に等しい板厚方向に一様 なき裂がある場合の $K$ 値(Fig. 10 に示した $K$ 值)

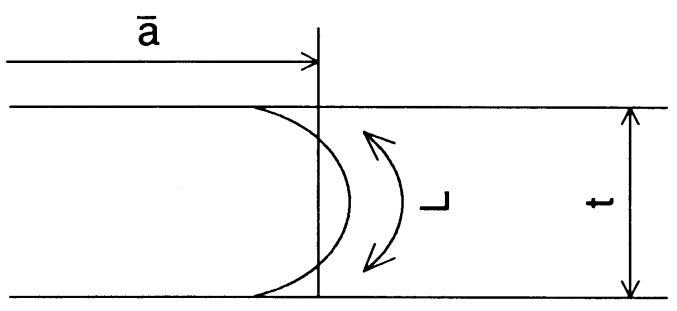

\section{Direction of crack propagation}

Fig. 11 Parabolic through-thickness crack

\section{$L ： き$ 裂前縁線の長さ}

で近似的に与えられる。ところで，I 型梁のフェイスにあ る表面き裂がウエブに伝播した初期の場合などでは, あた かもウエブの板厚がフェイスの幅に等しい物体の中を表面 き裂として伝播する ${ }^{20)}$ 。そこで,ここでは Fig. 9 にしたがう き裂形状を仮定し, 半楕円き裂の弧長の一部として $L$ を与 えることにする。すなわち，き裂形状の変化を Fig. 9 のよ うに仮定しているから,

$$
a / c=\frac{a_{1}-a}{a_{1}-r_{0}}
$$

ただし

$r_{0}:$ 初期半円き裂の半径 (結晶粒径)

によりアスペクト比は変化する。また，き裂の面積 $S$ は

$$
\begin{aligned}
s & =\frac{2 a}{c} \int_{0}^{t / 2} \sqrt{c^{2}-x^{2}} d x \\
& =\frac{a t}{4 c} \sqrt{4 c^{2}-t^{2}}+a c \sin ^{-1} \frac{t}{2 c}
\end{aligned}
$$

となる。ここで, 一様に板厚貫通き裂として伝播する場合 のき裂長さを $\bar{a}$ とすると $(9)$ 式を用い, 一様貫通き裂の場 合の面積と等值することにより

$$
\begin{aligned}
\bar{a} t= & \frac{t}{4\left(a_{1}-r_{0}\right)} \sqrt{4\left(a_{1}-r_{0}\right)^{2} a^{2}-t^{2}\left(a_{1}-a\right)^{2}} \\
& +\frac{a_{1}-r_{0}}{a_{1}-a} a^{2} \sin ^{-1} \frac{t\left(a_{1}-a\right)}{2\left(a_{1}-r_{0}\right) a}
\end{aligned}
$$

となる。この場合き裂前縁の長さ $L$ は

$$
\begin{aligned}
L= & 2 \int_{0}^{\phi} \sqrt{c^{2}-\left(c^{2}-a^{2}\right) \sin ^{2} \theta} d \theta \\
= & \frac{2 a}{a_{1}-a} \\
& \int_{0}^{\phi} \sqrt{\left(a_{1}-r_{0}\right)^{2}-\left\{-a^{2}+2 a_{1} a-\left(2 a_{1}-r_{0}\right) r_{0}\right\} \sin ^{2} \theta} d \theta
\end{aligned}
$$

ただし

$$
\phi=\sin ^{-1} \frac{t}{2 c}=\sin ^{-1} \frac{\left(a_{1}-a\right) t}{2\left(a_{1}-r_{0}\right) a}
$$

なお， $a_{1}$ より大きなき裂に対しては，板厚方向に一様な 貫通き裂としての取扱いができるので $K=K_{1}$ となる。 


\section{5. 微小き裂領域のき裂伝播速度の整理と考察}

これまでき裂長さとしては表裏面, $1 / 4 t, 1 / 2 t, 3 / 4 t$ の位 置のき裂長さの平均とコンプライアンスの関係をあらかじ めビーチマーク法により調べ, 疲労き裂伝播中に計測され たコンプライアンスよりき裂長さを求める方法を採用して きた ${ }^{2)}$ 。コンプライアンスとき裂長さの関係としては上記 のように平均き裂長さの方が良く一本の曲線にのるものと 考えられる。しかし, 本試験片のような切欠底の多数点か らき裂が発生し，それらが合体して 1 つのき裂となる過程 ではそれらのき裂の面積を求めることができない。

したがって, 本節以後のき裂長さとしては板厚中央部の き裂長さとコンプライアンスの関係を較正曲線として与 え, コンプライアンスから板厚中央部のき裂長さを求めて 議論することにした。なお，比較のために用いる長いき裂 に対する ( 1 ) 式は板厚中央部のものではないが長いき裂に 対しては板厚中央部のき裂長さと平均き裂長さの差はほと んど $K$ 值に影響を与えないのでこれを修正しないで使用 した。

Fig. 12 に 2 節で行った CT 試験片の疲労試験中に計測 した RPG 荷重を示す。図中には同時に計測した最大荷重 および最小荷重の結果も示した。図に示すように, RPG 荷 重は切欠底からき裂が発生した直後はき裂の進行とともに 減少し極小值を示した後き裂の進展とともに大きくなり, あるき裂長さ $a_{1}$ のところで極大值を示し, その後き裂の進 展とともに徐々に減少する傾向が認められる。なお，応力 比が 0.05 の場合に最終段階でさらに RPG 荷重が上昇し ているのは，き裂の進行とともに油圧源の容量が小さいた めに最大荷重が低下し, 最小荷重が上昇しているためと理 解できる。

そこで，計測された $a_{1}$ をもとに Fig. 9 に示したアスぺ クト比の変化を仮定して 4 節で示した $K$ 値を計算した。そ の結果を $R=0.05$ の条件下で得られた $a_{1}=1.47 \mathrm{~mm}$ の場 合について Fig. 13 に示す。偏平なき裂ほど, 同一き裂深さ では $K$ 值が大きくなるので初期は case $\mathrm{C}$ の場合が最も $K$ 值は大きくなる。そして, 常に均衡成長をすると仮定し た case $\mathrm{A}$ が最も $K$ 值が小さくなる。 $R=0.3$ および $R=$ 0.5 の条件下で得られた $a_{1}$ をとにした結果についても Fig. 13 と同様の結果が得られた。

Fig. 14 は，き裂伝播速度と $\Delta K$ との関係を示したもの で, $\Delta K$ としては case A, case B, case Cの 3 つのアス ペクト比を仮定して得たものである。図中の実線はステー ジIIにおける $\Delta K \sim d a / d N$ の関係を示している。ここで は, コンプライアンス計測結果より得た $a \sim N$ 曲線をスム ージングして $d a / d N$ を求めている。アスペクト比の変化は 前述の考察からわかるように, $R=0.05$ から $R=0.5$ と応 力比が大きくなるにつれて case B と case Cの中間から case B 寄りのところを出発点として case Aへと近づいて

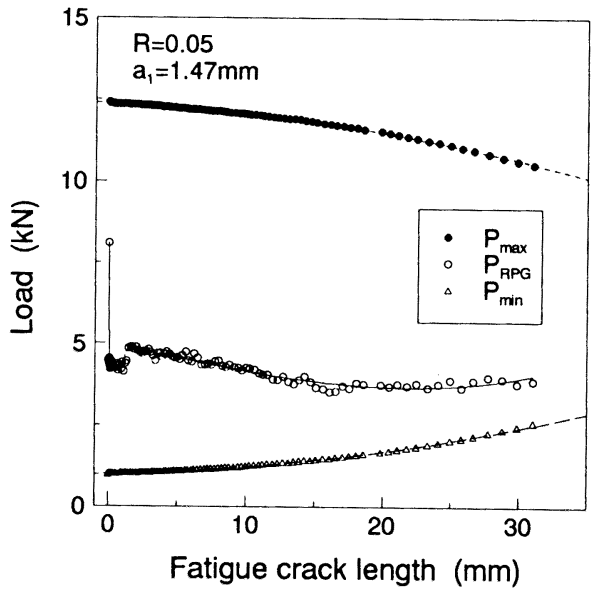

a) $\mathrm{R}=0.05$

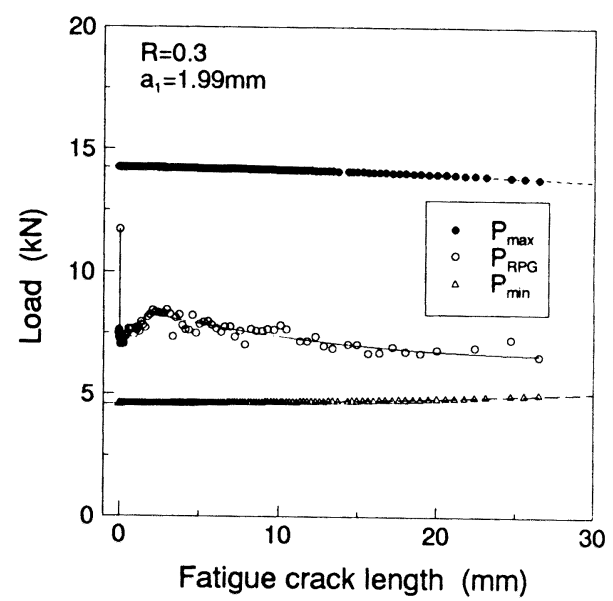

b) $R=0.3$

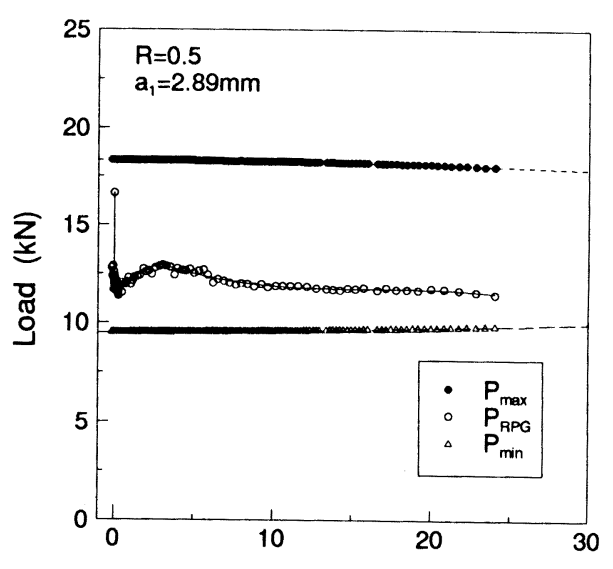

Fatigue crack length $(\mathrm{mm})$

c) $R=0.5$

Fig. 12 Measured RPG load plotted against measured crack length for constant amplitude loading test 


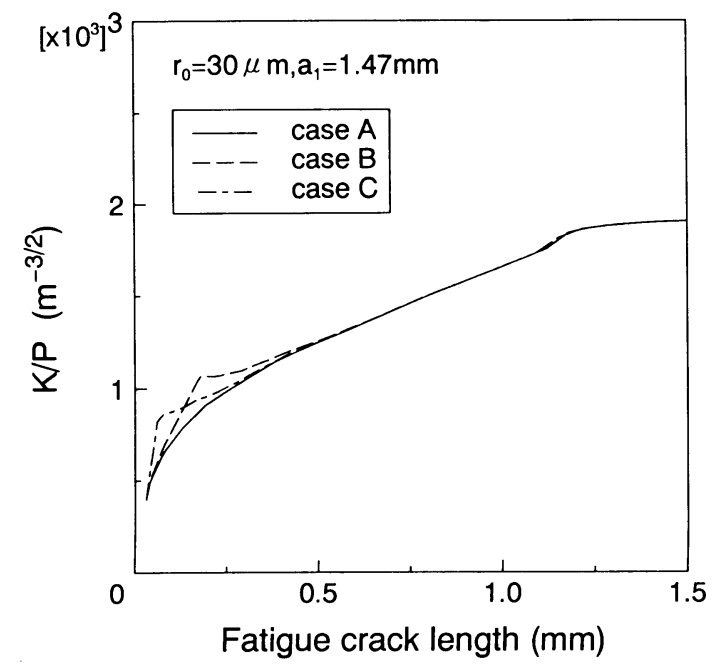

Fig. $13 K$ value for short crack emanated from a notch $(R=0.05)$

いくと考えられる。いずれにしても, 図より微小き裂領域 の疲労き裂伝播速度は, 長いき裂で得られるそれより同一 $\Delta K$ で比較すれば速くなり，これまでの研究結果 ${ }^{21), 22)}$ と同 様の傾向にあることがわかる。

そこで，計測された RPG 荷重と最大最小荷重から有効 荷重比 $U$ を求め，（5)式あるいは（８)式の $\Delta K$ に乗じて $\Delta K_{\mathrm{RP}}$ を求め, 疲労き裂伝播速度との関係を調査した。その 結果を想定したアスペクト比変化の case 毎に Fig. 15 に 示す。図中白ぬきの記号がき裂長さが $a_{1}$ 以下のものであ る。また, 図中括弧内の数字は計測した中で最も小さいき
裂長さを示す。ただし，この值は $a \sim N$ 曲線上でスムージ ングしたものである。また, 図中の実線は長いき裂に対し て得られた (1) 式を示している。応力比が大きくなるほど, アスペクト比変化は case A に近づくものと想定できるか ら,この結果をみれば, 微小き裂領域では $\Delta K_{\mathrm{RP}} \sim d a / d N$ 関 係は長いき裂のそれにほぼ一致すると結論づけることがで きる。

しかし， $a_{1}$ 以下の小さいき裂はき裂伝播過程におけるき 裂形状の変化過程の仮定および切欠底に存在する表面き裂 の $K$ 值の近似などにかなりの問題を含んでいる。

そこで, Fig. 12 に示した RPG 荷重の計測結果を図中に 示すようにスムージングし，長いき裂に対して得られてい る (1) 式を使用して 4 節で示した方法を適用し, 平均結晶 粒径 $(30 \mu \mathrm{m})$ を半径とする半円が切欠底に発生したとし て, この発生寿命は無視し, 計測した最大荷重および RPG 荷重の変化を与えてき裂成長曲線を計算した。

その結果を実験結果と合わせて Fig. 16 に示す。き裂成 長曲線でみるとアスペクト比を case A, case B, case C と変化させても推定寿命に大きな差異は生じないことがわ かる。さらに, $30 \mu \mathrm{m}$ という微小なき裂からの伝播寿命の 計算にもかかわらず, 実験結果よりも寿命が短くなってい る。しかし, 平行移動すれば計算されたき裂成長曲線は実 験結果によく一致しているようにみれる。すなわち, 1 結 晶粒に入るき裂発生寿命が全寿命に占める割合はかなり大 きいことが推定される。

\section{6. 微視き裂の成長曲線推定法の検討}

微小き裂の $\Delta K_{\mathrm{RP}}$ と疲労き裂伝播速度の関係は長いき裂 のそれにほぼ一致することが前節の結果から明らかとなっ

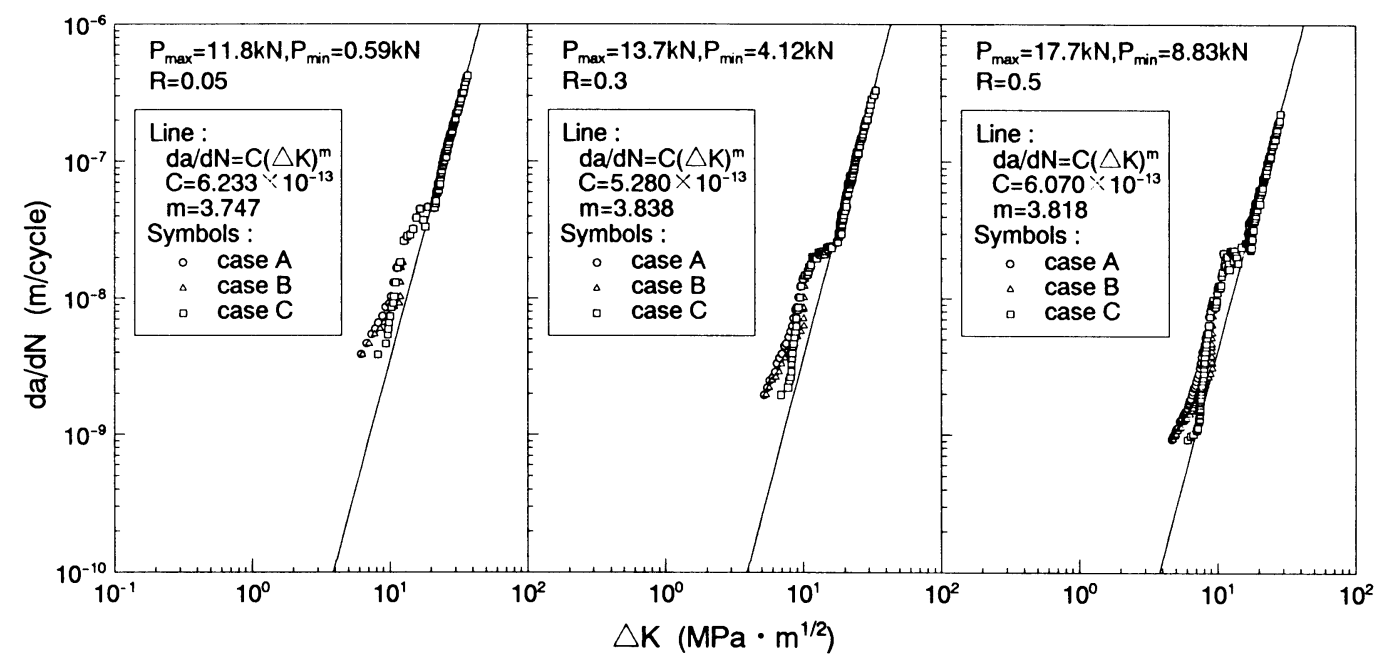

Fig. 14 Relationship between crack propagation rate and stress intensity factor range for short crack 


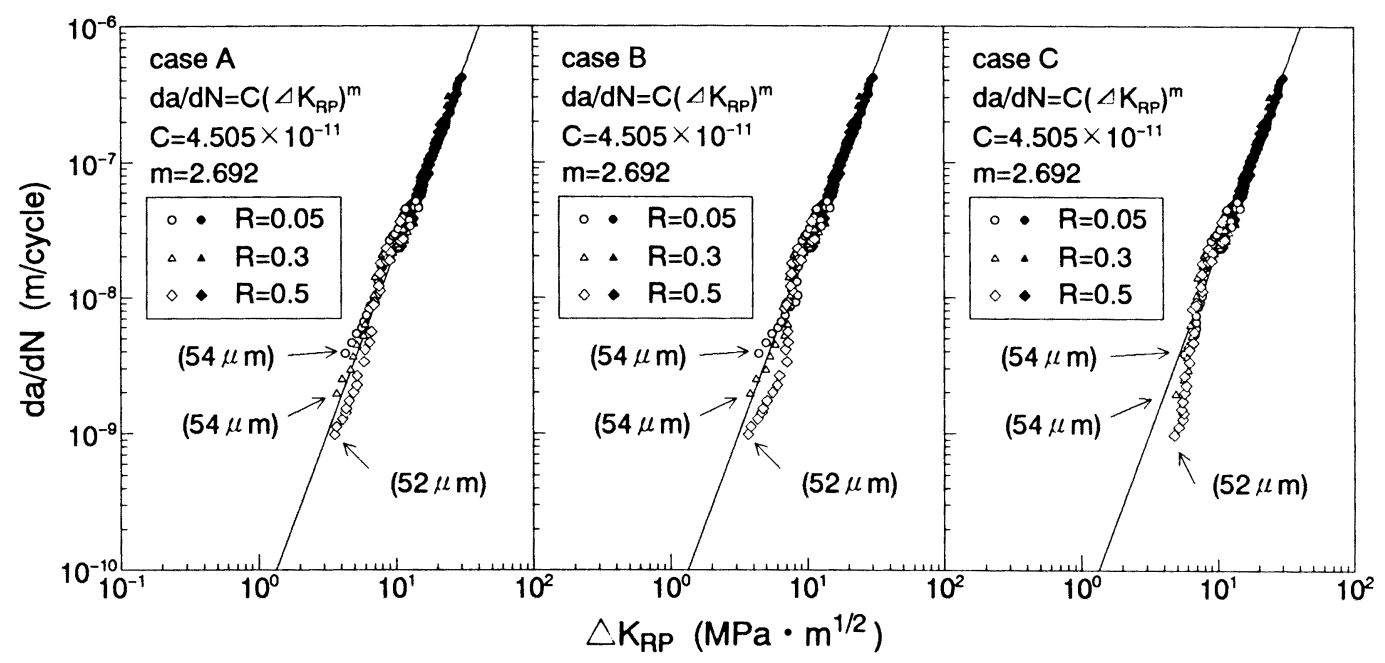

Fig. 15 Relationship between crack propagation rate and effective stress intensity factor range based upon RPG load for short crack

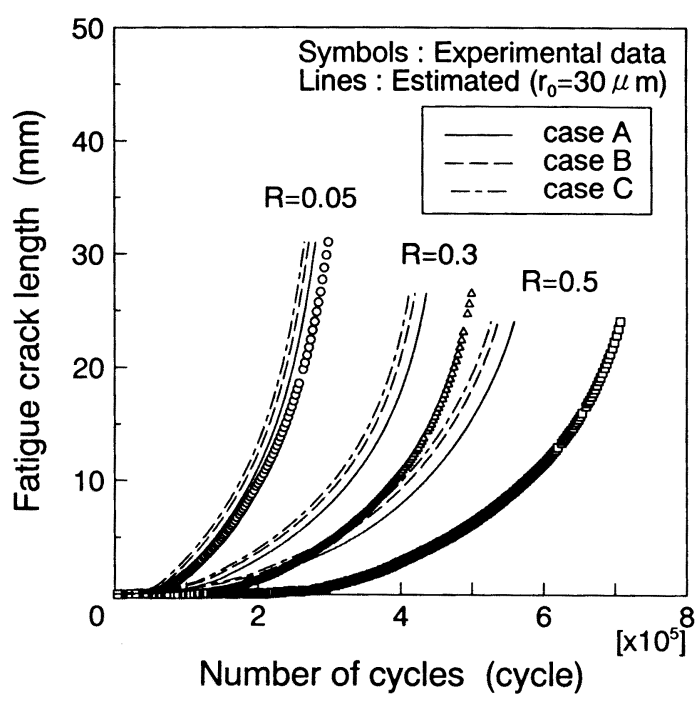

Fig. 16 Comparison between experimental crack growth curves and estimated ones without initiation life

\section{た。}

結晶粒径オーダ以下の微視き裂では応力の特異性が保証 されないので, $K$ 值をもとに疲労き裂伝播速度を議論する ことができず, 塑性域寸法との関係でこれまで検討されて きている。

ところで, 疲労き裂先端には最小荷重時に圧縮塑性域が 形成される。繰り返し荷重下ではき裂前方に形成される最 小荷重時の圧縮塑性域寸法の $\widetilde{\omega}$ の領域のみに両振り塑性 状態が形成される。
長いき裂では，周りの大きな弾性域(除荷弾性域も含む) に囲まれたき裂先端近傍の塑性域内の応力/ひずみ分布は 第一近似として塑性域寸法に依存すると考えられるので, き裂前方のき裂先端近傍に蓄えられる疲労被害分布は の関数となることが期待される。

๗の計測はできないのでここでは一様応力の繰り返し を受ける無限板中のき裂開閉口挙動をシミュレーションプ ログラム ${ }^{23)}$ で調査した。

Fig. 17 は初期の自然き裂半長を $10 \mathrm{~mm}$ とし一定応力振 幅下で伝播する場合の RPG 応力を求めた結果である。そ して, 同時に最小応力時の圧縮塑性域寸法 $\tilde{\omega}$ も求めた。 そこで，き裂閉口が生じないとし，応力比 0 の状態で $\left(S_{\max }-S_{\mathrm{RPG}}\right)\left\{S_{\max }\right.$ : 最大応力, $S_{\mathrm{RPG}}$ : 応力 $\}$ を最大応力とす る繰り返し応力を作用させた場合に生じる最小荷重時の塑 性域寸法 $\omega$ を Dugdale モデルより求め, $\widetilde{\omega}$ と関係を調 查した。その結果を Fig. 18 に示す。疲労き裂発生直後を除 き $\tilde{\omega}$ と $\omega$ は比例し, しかも応力比 $R$ および作用応力振幅 が異なってもその比はほほ一定となっている。

したがって， $\Delta K_{\mathrm{RP}}$ は長いき裂に対して最小荷重時に生 じる圧縮塑性域寸法を規定していることになり，疲労き裂 伝播速度は

$$
\frac{d a}{d N}=C(\tilde{\omega})^{m}
$$

ただし $C, m:$ 材料定数

として $\Delta K_{\mathrm{RP}}$ により間接的に取扱っていることになる。

Williams ら ${ }^{24)}$ はCT 試験片を用いてモード I, 薄肉円 筒試験片を用いてモード I とIIの組み合わせ，さらには円 筒切欠底のき裂試験片を用いてモードIIIの疲労き裂伝播試 験を行い, エネルギー解放率 $\Delta J$ より算出される弾塑性下 


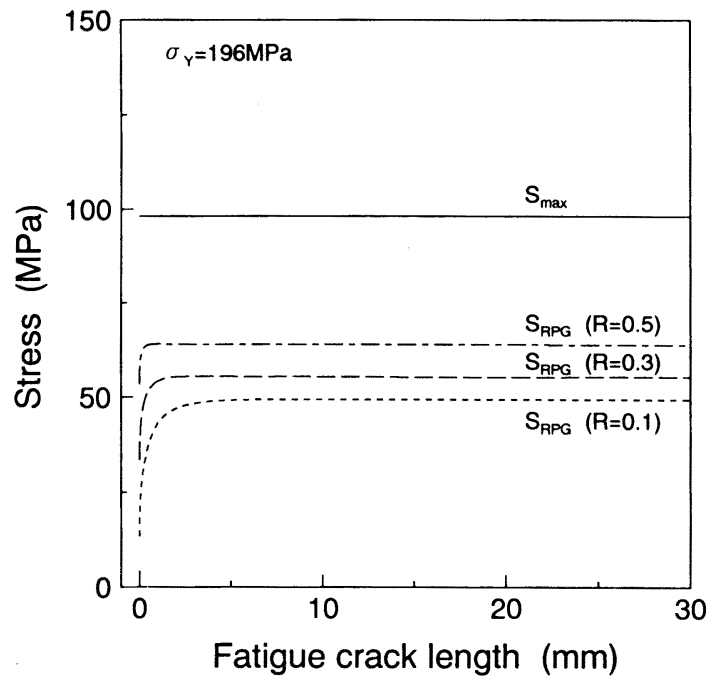

Fig. 17 The change of RPG stress for a crack body in an infinitely wide plate subjected to cyclic uniform stress with various stress ratios

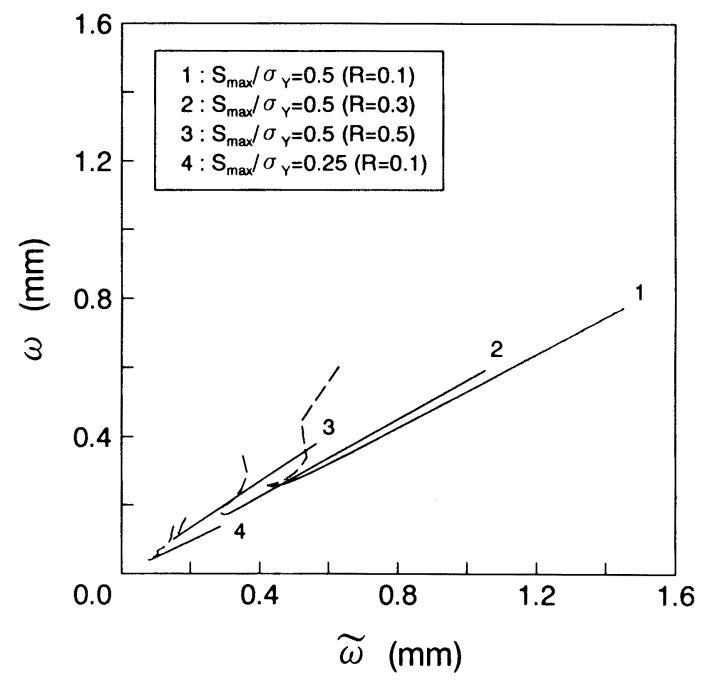

Fig. 18 Relationship between $\omega$ and $\tilde{\omega}$

の等価な応力拡大係数範囲を用いてき裂伝播速度を整理し た。そして，モードI とIIの混合モードならびにモードIII における疲労き裂伝播速度は, モード I の疲労き裂伝播速 度と一致することを示した。長いき裂に対しては, $\Delta J$ は塑 性域寸法と比例関係を有するから，(13)式（したがって， (1)式の表現法でも) はせん断モードに対しても成立する と期待される。

疲労き裂は, 最初せん断応力の繰り返しにより発生する。 微視き裂領域においても(13)式が成立すると仮定すると, この場合 $C, m$ はモードによる変化を考える必要はないこ

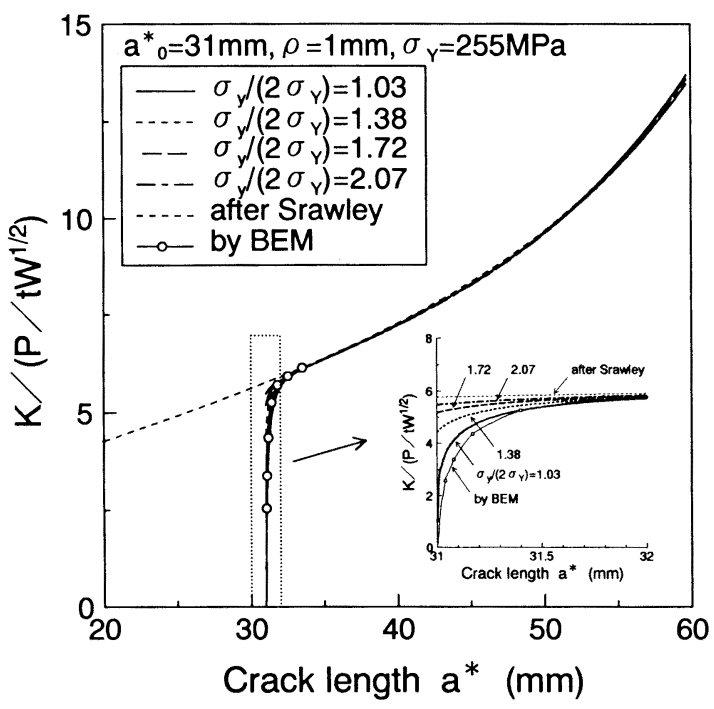

Fig. 19 Relationship between equivalent $K$ values and crack length

とになる。

ところで, Fig. 19 は CT 試験片のき裂面に集中荷重が作 用する場合の $K$ 値 ${ }^{25)}$ と Fig. 1 の試験片の切欠線上の応力 分布 (BEM による弾性解) を用いて, き裂閉口現象は生じ ないとして Dugdale モデルにより最小荷重時の圧縮塑性 域寸法 $\omega$ を求め，小規模降伏条件下における $K$ 值と塑性 域寸法の関係より, 以下のように等価 $K$ 値 $K_{\mathrm{eq}}$ を求めた 結果である。

$$
K_{\mathrm{eq}}=2 \sigma_{Y} \sqrt{\frac{8}{\pi} \omega}
$$

ここで, 塑性域寸法の計算においては降伏点として繰り返 し荷重下ということを考慮して, 静的降伏点の 2 倍の值を 与え, 応力比は 0 の状態とした。図中には, 切欠底の弾性 応力全振幅 $\left(\sigma_{y}\right)$ と $2 \sigma_{Y}$ との比を種々変化させた結果を示 している。また, Fig. 10 で求めた $K$ 值およびSrawleyに よる CT 試験片の $K$ 値 ${ }^{16)}$ も示している。

き裂が長くなると $K_{\mathrm{eq}}$ は CT 試験片の $K$ 值と良く一致 している。しかし, 切欠底で $2 \sigma_{Y}$ 以上の応力振幅が作用す る場合には, き裂が入っていない状態でも塑性域が形成さ れるため $K_{\mathrm{eq}}$ は 0 とならない。

上記の検討は貫通き裂が最初から発生し, 最小荷重時に もき裂が閉口しないと仮定したので, 最大荷重から最小荷 重の全振幅が圧縮塑性域の成長に全て有効に働いている場 合のものである。

Fig. 18 の検討より, 長いき裂に対しては RPG 荷重から 最大荷重にいたる荷重振幅 $\left(\Delta P_{\mathrm{RP}}\right)$ が圧縮塑性域長 $\widetilde{\omega} を$ 定していることになる。塑性域の成長は, RPG 荷重以上で 生じるから, 微視き裂に対しても $\Delta P_{\mathrm{RP}}$ が $\bar{\omega}$ の成長に寄与 
するとまず仮定する。

そこで, 以下では, $\Delta P_{\mathrm{RP}}$ が一定の場合について考える。 き裂は过り線に沿って発生すると考えられるが，き裂が 1 結晶粒程度になると疲労被害を受ける場所はほとんどき裂 先端に限られ，き裂が応力およびひずみの集中源として作 用し, 塑性変形がき裂先端付近に繰り返されながらき裂が 伝播することが微視的観察結果から明らかにされてい $3^{26)}$ 。过りは結晶粒の結晶方位と関係した特定の方向にし か生じないから, 切久底から入るき裂を考えた場合 Fig. 20 に示すように切欠底の第 1 番目の結晶粒に入る汇り方向と 結晶粒界を越えて次の結晶粒に入る过り方向は異なる。

刃状転位密度分布を考えた BCSS モデル27) からわかる ように，き裂が汇り線に沿って入ると，き裂先端近傍の転 位密度は極端に大きくなる。しかし, 刃状転位のバーガス ベクトルは过り線に平行なため,き裂が最初の結晶粒界に 達するまではき裂前方の高密度部分の刃状転位によるき裂 開口成分はほとんど生じないものと考えられる。しかし， き裂が最初の結晶粒界に達すると次の結晶中の刃状転位の バーガスベクトル $\left(b_{2}\right)$ が最初の結晶粒のバーガスベクト ル $\left(b_{1}\right)$ と異なるため, $b_{2}$ の $b_{1}$ に垂直な方向の成分をもつ 転位がき裂先端近傍に高密度で存在するようになり，き裂 開口モードが大きく生じ，それによりき裂が応力集中源の 役割を演じるようになると考えると上記の観察結果を定性 的に説明できる。

疲労き裂が入る前は，転位は切欠前方の結晶粒界などの あるバリヤ $(B)$ でくぎづけされていると考えられ，この位 置が塑性域先端になる。疲労き裂が入ったとしても最初の 結晶粒界に達するまではせん断によりき裂が入るため, 転 位の増殖はき裂先端近傍に限られ，上記のバリヤを転位は 飛び越えることができず，1 結晶粒以上になると転位はき 裂が応力集中源として作用するため $B$ のバリヤを越えて 塑性域が成長するものと考えることができそうである。

したがって, $\Delta P_{\mathrm{RP}}$ が一定の条件では, 最初の結晶粒界ま でき裂が成長する間は圧縮塑性域先端は切欠前方のある位 置に留まっていると仮定できる。き裂が結晶粒界に達した 時の $\widetilde{2}$ 求めるためには, き裂閉口域の影響を考慮する必 要があるので簡単には求められない。

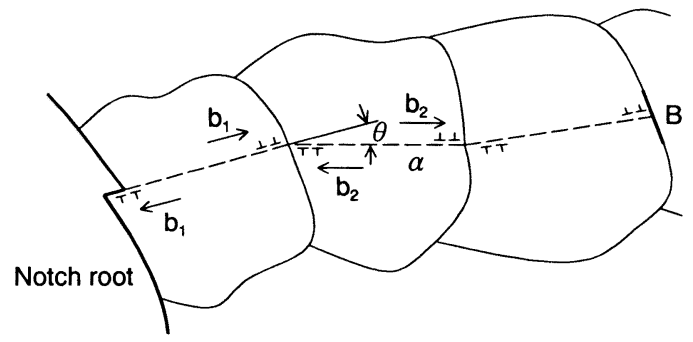

Fig. 20 Modification of slip direction at grain boundary
そこで， $\Delta P$ がすべて圧縮塑性域形成に有効に役立って いる場合を考え, すなわち, き裂閉口が生じないと仮定し, 1 結晶粒界まで表面き裂が達したときの $\Delta K$ 值を $\Delta K_{s}$ と すると，そのときの塑性域長さ $\omega_{s}$ は(14)式より

$$
\omega_{s}=\frac{\pi}{8}\left(\frac{\Delta K_{s}}{2 \sigma_{Y}}\right)^{2}
$$

ただし， $\Delta K_{s}$ は（5)式より求められる。

結晶粒径を $r_{0}$ とすると塑性域先端位置は $\left(r_{0}+\omega_{s}\right)$ とな る。したがって， 1 結晶粒より短いき裂に対する等価 $\Delta K$ 値 $\Delta K_{\text {eq }}$ は

$$
\begin{aligned}
\Delta K_{\mathrm{eq}} & =2 \sigma_{Y} \sqrt{\frac{8}{\pi}\left(r_{0}+\omega_{s}-a\right)} \\
& =2 \sigma_{Y} \sqrt{\frac{8}{\pi} r_{0}+\left(\frac{\Delta K_{s}}{2 \sigma_{Y}}\right)^{2}-\frac{8}{\pi} a}
\end{aligned}
$$

となる。そこで, 長いき裂に対してと同様 $\tilde{\omega}$ は $\Delta K$ に有効 荷重比を乗じたもので間接的に表されると仮定する。すな わち,

$$
\begin{aligned}
& \Delta K_{\mathrm{RP}}=U \cdot \Delta K_{\mathrm{eq}} \\
& \text { ただし } \\
& U=\frac{P_{\max }-P_{\mathrm{RPG}}}{P_{\max }-P_{\min }}
\end{aligned}
$$

として近似的に与えられることになる。

Fig. 21 には上記の手法により, Fig. 9 に示したように表 面き裂形状変化を case A, case B, case Cの 3 つを仮定 して,き裂長さ 0 の状態から伝播するき裂の成長曲線を 種々の結晶粒径を有するとして，2 節で行った CT 試験片 で計測された最大荷重 $P_{\max }$, 最小荷重 $P_{\min }$ および RPG 荷 重 $P_{\mathrm{RPG}}$ を用いて推定した結果を実験結果とともに示した。 この結果をみると, case A〜case C と初期のアスペクト比 の変化を仮定しても, Fig. 13 から予想されるごとくこれら の間には寿命に大きな差異が生じないことがわかる。そし て, 結晶粒径を $30 \mu \mathrm{m} \sim 45 \mu \mathrm{m}$ とすれば実験結果と非常に 良い一致が認められる。R が大きくなるほど前述のように アスペクト比変化は case A に近くなることを考慮すると さらに実験結果と良い一致が認められる。

ところで, 本供試試験片の場合疲労き裂は切欠底の板厚 中央部で生じるが, 最初にき裂が入るのは塑性せん断ひず みによるはずであり，この場合き裂底での結晶の过り面で ある $\{110\},\{112\},\{123\}$ のいずれかが巨視的なすべり方向 に一致する結晶に入り，その内の最も大きな結晶粒に入っ たき裂がき裂の核として成長していくものと考えられる。 したがって, 切欠の前縁線で結晶粒が切断されることも考 えれば, $30 \mu \mathrm{m} \sim 45 \mu \mathrm{m}$ という結晶粒径は Fig. 2 の結果か ら妥当なものであると考えられる。

なお，Fig. 2 をみると板厚方向には圧延の影響で結晶粒 が細かくなっているが，主き裂は板面に平行に進展するよ うに試験片が採取されており，板厚方向に伝播するき裂は たとえ結晶粒界で進展が妨害されたとしても主き裂方向が 深くなり，主き裂方向に偏平なき裂になると，切欠底表面 
の $K$ 值が主き裂方向の $K$ 值より大きくなるために容易に 飛び越えることができるものと推察される。また，もし飛 び越えないとしても Fig. 13 からわかるように最深部の $K$ 值にはあまり顕著な影響を与えないものと考えられる。

以上のように, 疲労き裂の発生を $S-N$ 線図を使用する ことなく, き裂発生をもき裂の成長過程ととらえ, 初期き 裂の存在の仮定を導入することなく，同一き裂伝播理論体 系で疲労寿命が推定できる可能性が示された。Fig. 21 の計 算結果をみると結晶粒径が細かくなるほど疲労寿命が長く なる傾向にある。これは, 従来の研究結果と定性的に一致 している。そこで, Fig. 22 には応力比 0.05 を意図した試験 片に対して結晶粒径の影響のみを調べるためにさらに細か い結晶粒径の場合についても疲労き裂伝播曲線（き裂発生 寿命を含む)を推定した結果を示した。この結果をみると， 結晶粒径を $10 \mu \mathrm{m}$ 程度以下にすると結晶粒径を細かくす るほど寿命改善効果が著しく現れるが, $20 \mu \mathrm{m}$ 以上ではあ まり疲労寿命の改善効果は結晶粒径を細かくしても大きく ないことが推察できる。

\section{7. 過去の微視き裂の研究結果と本取扱い法の整合 性に関する定性的検討}

6 節の取扱いは, 厳密な意味で最小荷重時の塑性域寸法 ひを与えているわけではなく，取扱いの単純化を考えた近 似的なものである。しかし，6 節の結果より，応力集中部 から発生・伝播する疲労き裂の成長曲線が初期潜在欠陌の 存在を仮定することなく $\Delta K_{\mathrm{RP}}$ と $d a / d N$ の関係および RPG 荷重から非常に精度良く推定できている。

この取扱いにかかわる物理的意味のさらに詳細な検討は 今後の研究に委ねざるを得ないが, 微視き裂特有の挙動に ついて 6 節のアルゴリズムで定性的に説明できるか否かを 検討してみた。微視き裂特有の現象としては,

（1）低 $\Delta K$ 領域でき裂の成長とともに伝播速度が速 くなったり遅くなったりする挙動を繰り返す3)。

（2）切欠半径がある值以下になると切欠底に停留き裂 が観察されるが，ある值以上になると停留き裂は観 察されない28)。

（3）停留き裂が生じた材の疲労限は処女材の疲労限よ り大きくなるいわゆるコーキシング効果 ${ }^{29)} 。$

の 3 つの現象が知られている。そこで，これらについて定 性的に説明できるか否かを検討した。

（1）低 $\Delta K$ 領域におけるき裂伝播速度の早遅繰り返 乙現象

Fig. 233) はNavarroらにより得られたフェライト鋼を 供試材とする平滑試験片に一定荷重振幅を与えた場合の疲 労き裂伝播速度とき裂長さの関係を示したものである。こ の関係は試験片表面でとらえたもので, 疲労き裂は表面き 裂状に伝播している。始め結晶粒内に入った微視き裂はき 裂前方に存在するパーライトでも進展を妨害されるが，セ

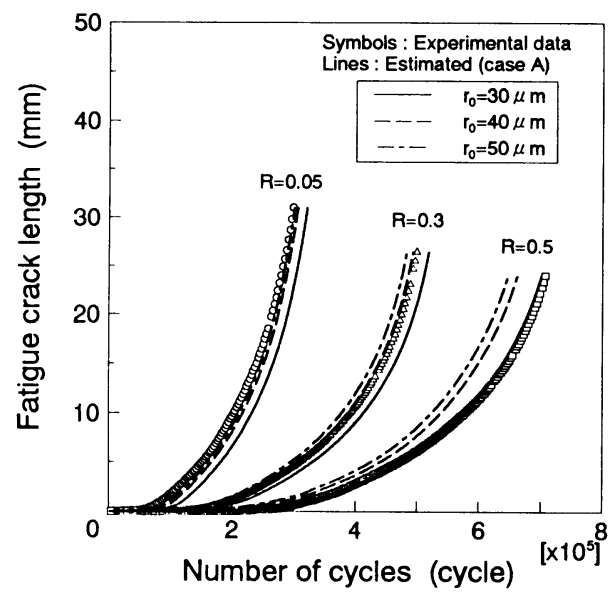

a) case $A$

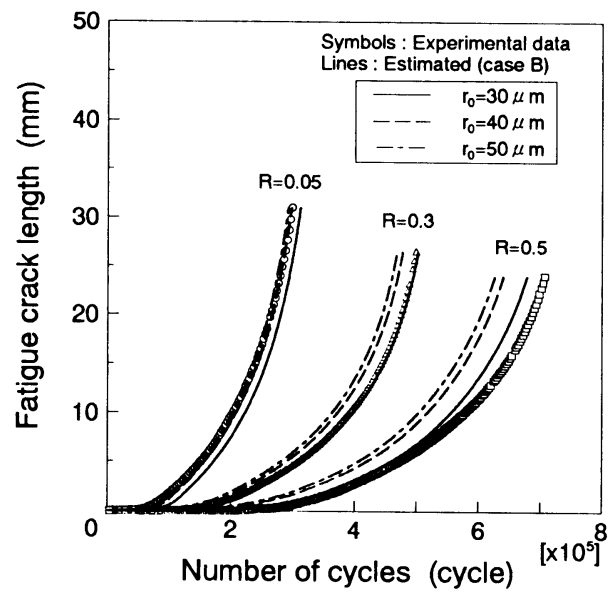

b) case $B$

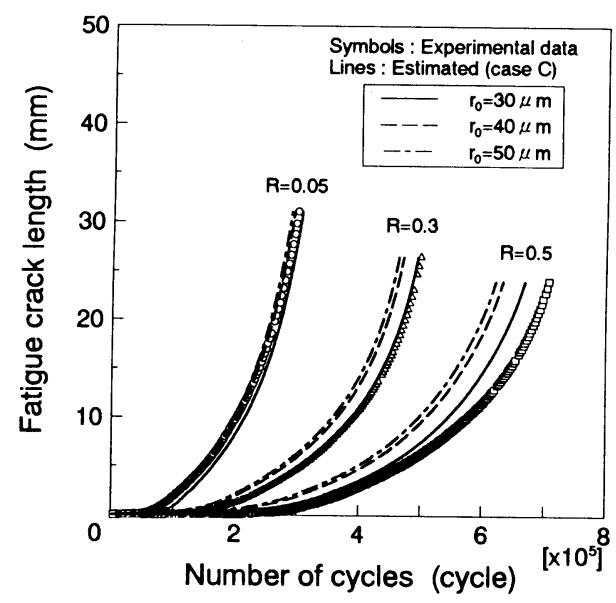

c) case $\mathrm{C}$

Fig. 21 Comparison between experimental crack growth curves and estimated ones for various grain sizes 


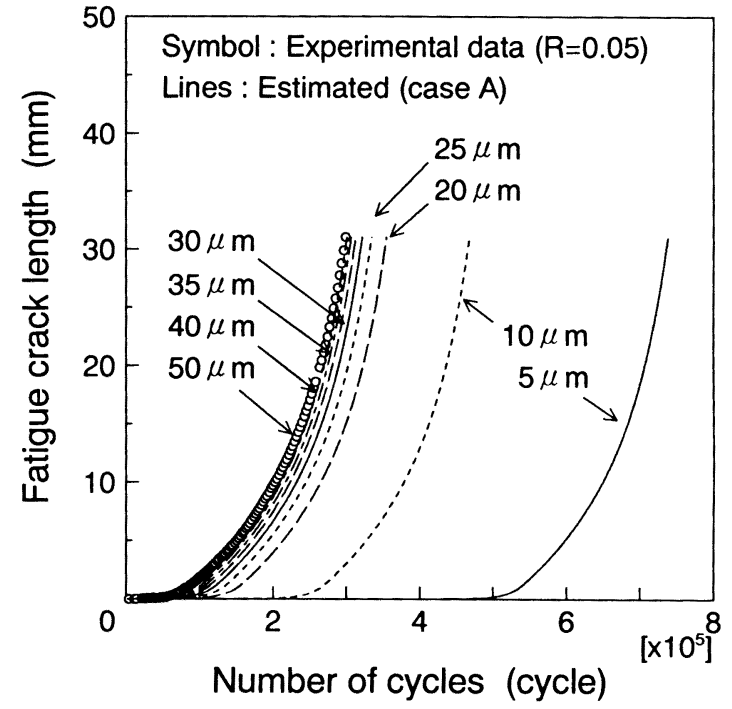

Fig. 22 Estimated crack growth curve for steels with various maximum grain sizes $(R=0.05)$

パレーション材でき裂がマイクロセパレーションを包み込 んでき裂が成長する ${ }^{30}$ のと同じように，マトリックスであ るフェライトが結晶粒内には連続して存在しているため, パーライトを包み込んでき裂はフェライト部を伝播し, 連 続して存在する結晶粒界でき裂の成長が妨害されるものと 考えられる。

彼らは, 試験片表面でき裂の成長を観察していることか ら，1結晶粒程度き裂が進む間に表面に存在するパーライ トにき裂が何回も成長を阻止されるのでこのような結果を 得たものと考えられる。すなわち，この領域ではき裂は表 面き裂であり，表面き裂全体としては阻止されることなく フェライト地を伝播していると考えると彼らの結果も理解 できる。

事実，アルミ青銅を供試材とする平滑試験片を用いて行 った Tayler ら ${ }^{21)}$ の結果では, 微視き裂領域ではき裂の成 長とともに $d a / d N$ が小さくなるのは 1 回しか観察されて いない。

\section{（2）切欠底の停留き裂}

Fig. 1 の試験片を用いて応力比 $R=0.05$ で $P_{\max }$ を 7.85 $\mathrm{kN}$ として疲労試験を行ったが，600万回繰り返し負荷を かけても疲労き裂が入った様子がなく, 試験を終了し, 切 欠底を顕微鏡により観察したが, 疲労き裂の発生は認めら れず，板厚中央部を注意深く切削しながら断面を観察して も停留き裂は認められなかった。

西谷は環状切欠を有する丸棒の回転曲げ疲労試験を実施 し, 炭素鋼では切欠半径が $0.5 \mathrm{~mm}$ 以下では停留き裂が認 められるが， $0.5 \mathrm{~mm}$ 以上では停留き裂は発生しないこと を示している28)。切欠底近傍の応力分布は西谷が提唱する 切欠力学 ${ }^{14)}$ によると切欠半径によりほぼ決定される。した

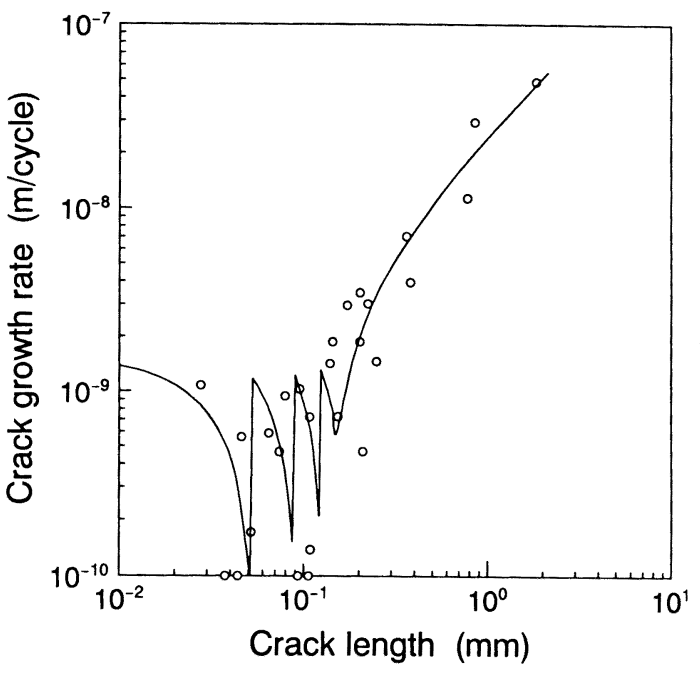

Fig. 23 Experimental short crack growth data after Navarro and de los Rios ${ }^{3)}$

がって, Fig. 1 の切欠半径が $1 \mathrm{~mm}$ の場合に停留き裂が認 められなかったのは西谷の結果と一致する。

Fig. 24 は, 微小き裂領域の $K_{\mathrm{eq}}, P_{\mathrm{RPG}}, U$ ならびに $U \Delta K_{\mathrm{eq}}$ の巨視的な変化挙動を切欠半径 $\rho$ に関連させて定性的に 示したものである。切欠半径 $\rho$ が小さくなるほど応力集中 が大きくなるため 1 結晶粒にき裂が達した時の $K$ 值は大 きくなる。そのため, き裂閉口が生じないとして求められ る $K_{\mathrm{eq}}$ は $\rho$ が小さくなるほど大きくなる。 $\rho に は$ 無関係で 切欠長により応力分布が規定される領域までき裂が伝播す ると両者の $K$ 值は同じとなるのでa)に示す変化過程をた どる。

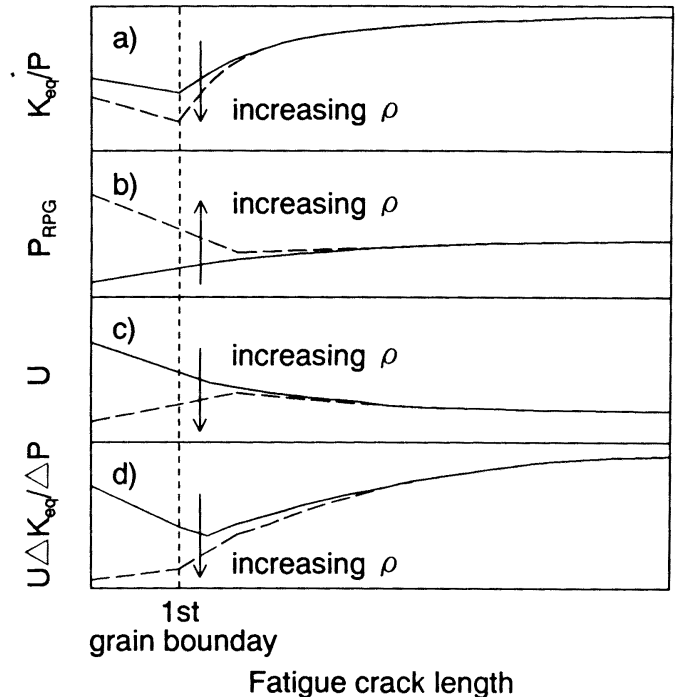

Fig. 24 Effect of a notch root radius on RPG load 
$\left(P_{\mathrm{RPG}}-P_{\mathrm{min}}\right)$ の荷重振幅に対応する切欠底の応力振幅が $2 \sigma_{Y}$ になった時, 引張塑性域が切欠底に生じ出すからき裂 が入る前は $P_{\mathrm{RPG}}$ は $\rho$ が大きくなるほど大きくなる。 $\rho$ が大 きい場合，き裂が入ることにより応力集中係数が大きくな るため $P_{\mathrm{RPG}}$ はき裂の成長とともに減少する。 裂状の場合には，き裂進展とともにき裂閉口域が成長する ため $P_{\mathrm{RPG}}$ は増加する。ここで, $\rho$ が大きい場合に,き裂の 成長とともに $P_{\mathrm{RPG}}$ が減少して最小値を示す時点は, き裂閉 口域の成長に関係しているはずであるから, 最初の結晶粒 界にき裂が達した時点, すなわち, $\Delta K_{\mathrm{eq}}$ が最小となる時点 とは一致せず計測結果からは 1 結晶粒よりも大きなき裂で $P_{\mathrm{RPG}}$ が最小になっている。そのため, 巨視的には b)のよう な変化を生じる。したがって, 有効荷重比 $U$ は c)のような 変化を生じる。

さらに, $U \Delta K_{\mathrm{eq}}$ は, a) と c)を乗じることにより d)のよう に $\rho$ が小さいと一旦き裂の成長とともに小さくなるが, $\rho$ が大きい場合には常にき裂の成長に伴い大きくなる現象が 生じる。したがって, $\rho$ が大きい場合には, 一旦き裂が発生 するとき裂成長とともにUAK $\mathrm{eq}$ が大きくなっていくから 停留き裂は観察されない。一方, $\rho$ が小さくなると, き裂成 長とともに $U \Delta K_{\mathrm{eq}}$ は一旦低下する。 $U \Delta K_{\mathrm{eq}}$ が 0 とならな くても $\Delta P$ をある程度小さくした試験においては $U \Delta K_{\mathrm{eq}}$ が小さくなり, 例えばき裂伝播速度が $10^{-12} \mathrm{~m} / \mathrm{cycle}$ 以下 となるとき裂が $0.01 \mathrm{~mm}$ 進展するのに $10^{7}$ cycle 以上かか るから事実上き裂は停留してしまうことになる。したがっ て, $\rho$ が小さい場合 $\Delta P$ が小さい試験では停留き裂が生じ るようになる。この場合, 停留き裂の深さはd)のように必 ずしも 1 結晶粒の大きさとはならない。以上のように上述 のアルゴリズムで西谷らの結果が定性的に説明できる。

なお, き裂前方に降伏点の高い材が存在すると一様材よ りもき裂が降伏点の高い材に近くにきた時 RPG 荷重が上 昇することがシミュレーション結果で求められている ${ }^{25)} 。$ したがって,この効果によっても停留き裂の大きさは異な ることが考えられる。

（3）コーキシング効果

疲労限より少し大きな荷重振幅で繰り返し負荷を受けて いる場合 (case H) と疲労限の荷重振幅で繰り返し荷重を 受け, 停留き裂となっている場合（case L）を考える。こ こで, case H は case L と同じ長さのき裂である場合を考 える。

停留き裂の場合のような小さなき裂は主としてせん断応 力の繰り返しで生じていると考えられるが, 引張モードも 当然わずかではあるが生じている。疲労き裂は, 最大荷重 時に生じるき裂前方の高引張塑性変形層をき裂内に除荷過 程で取り込み,この部分は最小荷重時には圧縮塑性変形し, 塑性変形層が小さくなるという現象を繰り返しているの で, case H の方が case L の場合よりも最大荷重時の変形 層を最小荷重時に圧縮変形させる量が大きくなり, その結
果として case Lの場合よりも case $\mathrm{H}$ の方が最小荷重時 のき裂閉口領域が小さくなる傾向にある。

ここで, case Lのき裂に case H の荷重を負荷させると 引張塑性変形層を最大荷重時に取り込んだとしてもこの部 分が受け持つ圧縮荷重は 1 サイクルで伝播するき裂長は非 常に短く,この部分は完全に圧縮塑性域になり, ほんの少 しの圧縮荷重しか受け持たない。したがって, き裂閉口域 はほとんど前の状態を保持し, き裂閉口領域は減少しない。

したがって, 最初から case $\mathrm{H}$ の荷重で負荷されたもの よりも case Lのき裂に case $\mathrm{H}$ の荷重で負荷したものの き裂閉口域は大きくなる。そのため, case Hよりも RPG 荷重は case L に case H の負荷をしたものの方が大きく なり, その分有効荷重振幅が小さくなる。このことからコ ーキシング効果が生じるものと考えられる。すなわち, $\mathrm{RPG}$ 荷重の変化でコーキシング効果も定量的に説明でき る可能性がある。

以上のように, 定性的には微視き裂特有の現象も説明で きる。今後特に上記 (2), (3)についてはシミュレーショ ンモデルを使用するなどして定量的な検討を行っていく必 要がある。

\section{8. 結 論}

切欠底から発生伝播する疲労き裂成長曲線を初期き裂の 存在を導入することなしに, 統一的理論体系下で予測する アルゴリズムの検討を行った。得られた結果を要約すると 以下のようになる。

（1）長いき裂に対して， $\Delta K_{\mathrm{RP}}$ はき裂先端近傍で塑性 のヒステリシスループが生じる最小荷重時の圧縮塑 性域寸法 $\tilde{\omega}$ を間接的に表している。

（2）RPG 荷重が極大值を示した後は貫通き裂として 取扱える。

（3）切欠底で発生する微小き裂は合体を繰り返し，つ いには 1 つの半楕円表面き裂となるが，この間のア スペクト比変化はき裂深さに対して線形的に減少す るとして 1 つの半楕円表面き裂問題として仮想的に 取扱うことにより寿命が簡易的に評価できる。

（4）完全にき裂が合体した後は RPG 荷重が最大值を 示すときにアスペクト比が 0 となる均衡成長の直線 に漸近するようにアスペクト比が変化する。

（5） 1 結晶粒以上の微小き裂に対する $\Delta K_{\mathrm{RP}} \sim d a / d N$ 関係は長いき裂のそれにほぼ一致する。

（6）有効荷重 (=最大荷重-RPG 荷重)が一定のとき, き裂が初めの結晶粒界に到達するまでは塑性域先端 位置は一定に保たれると仮定し, 等価な $K$ 值をき裂 閉口を無視した時に生じる圧縮塑性域寸法より求 め, 長いき裂に対してと同様, 有効荷重比を乗じた 等価な $\Delta K_{\mathrm{RP}}$ を採用すると,長いき裂における $\Delta K_{\mathrm{RP}}$ $\sim d a / d N$ 関係を使用して初期き裂の存在の仮定を 
用いることなくき裂成長曲線がき裂長 0 の状態から 推定でき，実験結果と良い一致を示す。

（7）上記アルゴリズムによると，結晶粒径が小さいほ ど疲労寿命は長くなる。大幅な寿命改善には $10 \mu \mathrm{m}$ 以下の結晶粒としなければならないことが計算結果 より推定される。

（8）上記アルゴリズムによると，切欠底に生じる停留 き裂はある曲率半径以下のものに限られることが定 性的に示され, この傾向は過去の研究結果と一致す る。また，コーキシング効果についても上記アルゴ リズムにより定性的に説明できる。

以上のように，応力集中場における疲労き裂の寿命評価 においては発生寿命を考えることなく，また初期き裂の存 在を仮定することなく，伝播計算で疲労寿命が評価できる 可能性が示された。しかし，初期のき裂のアスペクト比変 化について今後切欠半径および応力比の関数として与える ための研究を実施する必要がある。しかし，この変化は寿 命評価に大きな影響を与えないのである程度ラフなものて よい。

なお, 本研究は文部省科学研究費一般研究 (B)「研究代 表者：豊貞雅宏」の補助を受けて実施されたものである。 本論文に関し有益な示唆をいただいた日本造船学会材料・ 加工委員会の方々に謝意を表します。また，転位の挙動に 対しては九州大学工学部美浦康宏教授に有益な示唆を賜つ た。さらに, Fig. 10 の $K$ 値解析には九州大学工学部宮崎則 幸助教授らが開発した BEM による解析プログラムを使用 させていただいた。ここに記して謝意を表します。

\section{参 考 文 献}

1) K. J. Miller: Metal fatigue-past, current and future, Proceedings of the Institution of Mechanical Engineers, Vol. 205, (1991), p. 1, and "Keynote Lecture" at International Symposium "Fatigue Design '92", Finlandia Hall, Helsinki, Finland, May 19-22, (1992)

2）豊貞, 丹羽, 山口, 武中, 荒巻, 畺崎: 極低き裂伝播速 度領域における疲労き裂伝播則について, 日本造船 学会論文集, Vol. 172, (1992), p. 589

3) A. Navarro and E. R. de los Rios: A Model for Short Fatigue Crack Propagation with an Interpretation of the Short-long Crack Transition, Fatigue Fract. Engg. Mater. Struct., (1987), p. 169

4）川原, 栗原: 表面き裂の疲労による伝播成長過程に おける予備的考察，日本造船学会論文集，Vol. 137, (1975), p. 297

5) M. Toyosada, M. Tateishi and M. Kitazono: Fatigue Crack Propagation from an Initial Defect, Hitachi Zosen Technical Rev., Vol.39, No. 2, (1978), p. 48

6）岡本, 豊貞 : ブラケット端部からの疲労き裂発生伝 播挙動についてーLPG キャリアタンクコーナー部 材の疲労強度一, 関西造船協会誌, Vol. 175, (1979), p. 31

7）豊貞, 山口, 丹羽, 武中, 梶本, 矢島 : 新疲労き裂伝播 パラメータの提案と高精度コンプライアンス計測法 の開発，日本造船学会論文集，Vol. 169，(1991), p. 245

8）飯田, 安藤, 平田: 複数表面欠陥からの疲労亀裂伝 播寿命評価 (第一報), 一直列配置複数亀裂問題一, 日本造船学会論文集, Vol. 148, (1980), p. 284

9）日本溶接協会原子力研究委員会 6 AFC 小委員会： 原子力圧力容器及び配管の疲労強度評価に関する試 験研究, JWES-AE-7707, (1977)

10) J.C. Newman Jr. and I.S. Raju: Analysis of Surface Cracks in Finite Plates under Tension or Bending Loads, NASA Technical Paper, No. 1578, (1979)

11) A.S. Kobayashi : Crack Opening Displacement in a Surface Flawed Plate Subjected to Tension or Plate Bending, Proc. of the 2nd Int. Conf. on Mech. Behaviour of Materials, Boston, (1976), p. 1073

12) A. F. Blom, A. Hedlund, W. Zhao, A. Fathulla, B. Weiss and R. Stickler: Short Fatigue Crack Growth Behaviour in Al 2024 and Al 7475, Edited by K. J. Miller and E. R. de los Rios, The behaviour of short fatigue cracks, EGF publications 1 (Mech. Engg. Publications, London), (1986), p. 37

13）寺崎：私信

14）西谷：材料力学の進展一古いものから新しいものへ 一, 日本機械学会第 66 期全国大会特別講演, (1988)

15）宮崎, 池田, 祖田, 宗像：境界要素法による界面き裂 の応力拡大係数解析 (第 2 報, 経路積分法の適用), 日本機械学会論文集, A 編, Vol. 57, No. 544, (1991), p. 2903

16) J. E. Srawley: Wide Range Stress Intensity Factor Expressions for ASTM E399 Standard Fracture Toughness Specimens, Int. J. Fract., 12, (1976), p. 475

17) S. J. Maddox : An Analysis of Fatigue Cracks in Fillet Welded Joint, The Welding Institute E/49/ 72, (1972)

18) H. Tada, P. C. Paris and G. R. Irwin: The Stress Analysis of Cracks Handbook, Del Research Corp., Hellertown, Pa., (1973)

19) B. K. Neale : An investigation into the effect of thickness on the fracture behaviour of compact tension speciments, Int. J. Fract., Vol. 14, No. 2, (1978), p. 203

20）町田，的場，吉成，林，牧野：ブロック荷重を受ける 溶接構造の疲労寿命推定法に関する一考察, 日本造 船学会論文集, Vol. 172, (1992), p. 579

21) D. Taylor and J. F. Knott : Fatigue and Propagation Behaviour of Short Cracks - The Effect of Microstructure-, Fatigue Fract. Engg. Mater. Struct., Vol. 4, No. 2, (1981), p. 147

22）城野, 宋, 伊藤: 微小予き裂材の疲労き裂進展とき 裂開閉口挙動（高張力鋼 HT-80の場合）, 日本機械 学会論文集, A 編, Vol. 51, No.471, (1985), p. 2554 
23）豊貞, 後川, 丹羽, 武中 : 任意応力場における疲労き 裂伝播シミュレーション, 西部造船会会報, Vol. 83, (1991), p. 189

24) R. A. Williams and W. W. Wilkning: CombinedMode Low-Cycle Fatigue Crack Growth under Torsional Loading, ASTM STP-995, (1989), p. 388

25）豊貞,丹羽, 他：RPG 荷重のシミュレーション, 投稿 予定

26) 西谷編書 : 疲労強度学, 総合材料強度学講座 6 , 才ー 么社 (1985)
27) B. A. Bilby, A. H. Cottrell, E. Smith and K. H. Swinden: Plastic Yielding from Sharp Notches, Pro. Roy. Soc., A279, (1964), p. 1

28）西谷：炭素鋼の回転曲げ試験における分岐点ならび に疲れ限度の寸法効果 (小形材による検討), 日本機 械学会論文集, Vol. 34, No. 259, (1968), p. 371

29）西谷, 池永: 炭素鋼のコーキシング効果と微視的き 裂の関係, 機械の研究, Vol. 27, No. 8, (1975), p. 17

30）勝田，堺，豊貞：セパレーションを発生する鋼板の 疲労き裂伝播解析, 日本造船学会論文集, Vol.169, (1991), p. 257 